GEOLOGICAL SURVEY CIRCULAR 131

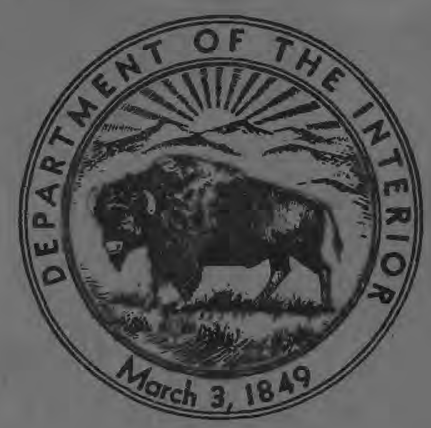

November 1951

\title{
EXPLORATORY DRILLING IN THE PRAIRIE DU CHIEN GROUP OF THE WISCONSIN ZINC-LEAD DISTRICT BY THE \\ U. S. GEOLOGICAL SURVEY IN 1949-1950
}

By

Allen V. Heyl, Jr., Erwin J. Lyons, and Allen F. Agnew

Prepared in cooperation with the Wisconsin Geological and Natural History Survey 


\section{UNITED STATES DEPARTMENT OF THE INTERIOR}

Oscar L. Chapman, Secretary

GE OLOGICAL S URVEY

W. E. Wrather, Director

Washington, D. C.

\footnotetext{
Free on application to the Geological Survey, Washington 25, D. C.
} 


\section{CONTENTS}

Fage

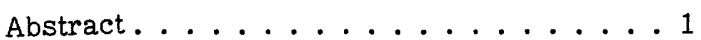

Introduction .............. 1

Historical data .......... 1

Cbjectives of project ........ 1

Acknowledgments.........4 4

Geology ................... 4

General features .........4

Stratigraphy ............ 4

Sulfide deposits ........ 5

General Characteristics .... . 5

Sulfides in the Galena, Decorah, and Flatteville formations ... . 5

Sulfides in the St. Feter sandstone. 5

Sulfides in the Frairie du Chien

group.......... 5

Sulfides in the Trempealeau and

Franconia formations ..... 5
Exploratory work by the Geological

Survey ............ 6

Froblems of drilling . ......6 6

Diamond drilling ...... 6

Churn drilling .......6 6

Results ............ 6

Crow Branch area ..... 8

Leix property. ........99

Farmley Harris property . . . . 9

Spitzbarth property. ...... . 9

Kennedy mine property . . . . . 9

James mine area ....... 11

Meekers Grove area. . . . . . 11

Vinegar Hill roaster property. . . 12

Conclusions ............ 12

Selected bibliography . . . . . . . . 16

Descriptive records of drill holes . . . . . 17

\section{ILLUSTRATIONS}

Figure 1. Index map showing outline of main productive area of the Upper Mississippi

Valley zinc -lead district and location of areas covered by detailed map of this report. . . . : 2

2. Generalized stratigraphic section of the Upper Mississippi Valley zinc-lead district. . . . . . 3

3. Geologic map and location of drill holes in Crow Branch area near Livingston, Wis. . . . . . . . 7

4. Flan view and geologic map and cross section in the nothwestern part of Crow Branch

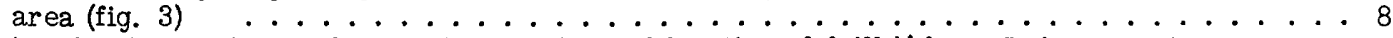

5. Map showing workings of $\mathrm{O}$. F. David mine and location of drill hole on Leix property near Montfort, Wis.. .............................10

6. Map showing location of drill holes on Spitzbarth and Harris properties near Mineral

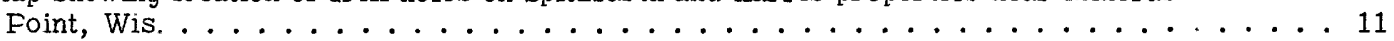

7. Map showing location of drill holes on Kennedy mine property near Hazel Green, Wis. . . . . 12

8. Map showing location of $\mathrm{dr}$ ill holes on James mine property near Shullsburg, Wis. . . . . . 13

9. Map showing location of drill holes on Raisbeck property, Meekers Grove area,. Wis. . . . . . . 14

10. Map showing location of drill holes on Vinegar Hill roaster property near Cuba City, Wìs. . . . 15 


\title{
EXPLORATORY DRILLING IN THE PRAIRIE DU CHIEN GROUP OF THE WISCONSIN ZINC-LEAD DISTRICT BY THE U. S. GEOLOGICAL SURVEY IN 1949-1950
}

\author{
By
}

\author{
Allen V. Heyl, Jr., Erwin J. Lyons, and Allen F. Agnew
}

\section{ABSTRACT}

The U. S. Geological Survey in cooperation with the Wisconsin Geological and Natural History Survey explored the Prairie du Chien group in the main productive area of the Wisconsin zinc-lead district during 1949-50. Eight properties--Crow Branch diggings, Leix, Harris, Spitzbarth, Kennedy, James, Raisbeck and Vinegar Hill Roaster--were explored using both diamond and churn drills. Twenty holes were drilled that totaled 8,582 feet in depth. The objectives of the exploration were to determine if the Prairie du Chien and other formations below the principal ore-bearing strata (Galena, Decorah, and Flatteville formations) of the district are favorable for ore deposits, and to determine the type of ore deposits, if present. Lean deposits of sphalerite, marcasite, and pyrite were found in the Frairie du Chien on five properties--Crow Branch, Leix, Harris, Spitzbarth, and Vinegar Hill Roaster-and also in the Franconia sandstone on the Leix property. In the drilled area the sulfides in the Frairie du Chien group occur in certain more brittle or soluble dolomite beds that contain cavities formed by brecciation or solution.

\section{INTRODUCTION}

\section{Historical data}

The Upper Mississippi Valley zinc-lead district (fig. 1) is one of the oldest mining areas in the United States. As early as 1658 (Thwaites, 1895, p. 272) lead ore was known in the area, and continuous active mining began in 1823 (Bain, 1900, p. 3). From about 1830 to 1871 the district was by far the most important lead-producing area in the United States. Zinc ore was first recovered from the mines about 1859, and production subse quently increased slowly. After 1902 more efficient mining and concentration methods were employed, and the production of zinc ore increased rapidly to a peak in 1917 , when 64,000 tons of zinc metal was produced. The activity of this period of mining has not been surpassed, although the years 1922-29 and 1942-50 were also important periods of mining.
Practically all of the ore mined to date (1950) has been recovered from the Galena, Decorah, and Platteville formations (fig. 2), but numerous deposits of sulfides, most of which lie north of the main productive part of the zinc-lead district as outlined in figure 1, were found in the underlying Prairie du Chien group during the nineteenth century. Although these lead, zinc, and copper deposits in the Frairie du Chien have been little explored and developed, a few deposits have been mined on a small scale. The principal localities of for mer commercial mining are: Chlerking diggings, secs. 31 and 32, T. 7 N. , R. 1 E. , 2 miles west of Highland, Wis.; Lansing lead mine, NW $\frac{1}{4}$ sec. 10, T. 99 N., R. 4 W. , 5 miles northwest of Lansing, Iowa; and Demby-Weist mine area, $N^{\frac{1}{2}} N^{\frac{1}{2}}$ sec. 29 , NW $\frac{1}{4}$ sec. $28, S^{\frac{1}{2}}$ sec.

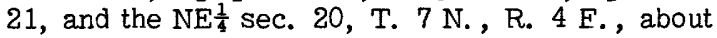
6 miles northeast of Dodgeville, Wis.

Galena was the principal ore mined in all of these places, but zinc ores also are present in the Demby-Weist mine area. Production statistics and information obtained locally indicate that mining was successful at these three places. Some of the geologists (Percival, 1855, p. 66; 1856, pp. 59, 63; Jenney, 1893, pp. 211-212) who examined these and the other ore deposits in the Frairie du Chien group, considered the possibilities good for ore deposits in these beds within the main productive area of the district; but others (Hall and Whitney, 1862, pp. 405-413; Chamberlin, 1882, pp. 554-560) very strongly opposed this view.

The drilling program described in this report was undertaken during $1949-50$ because the results of the geologic study of the district in progress from 1942 to the present (1950) favor the view that deposits of zinc and lead exist in the Prairie du Chien group within the principal mineralized area as suggested by Fercival and Jenney.

\section{Objectives of project}

The objectives of the exploratory program of diamond drilling and churn drilling, by the U. S. Geological Survey in cooperation with the Wisconsin Geological and Natural History Survey, were to 


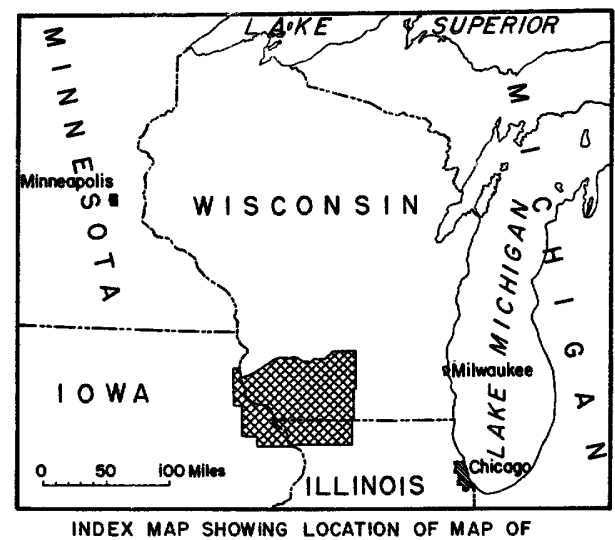

INDEX MAP SHOWING LOCATION OF MAP OF
ZINC-LEAD DISTRICT OF WISCONSIN, ILLINOIS, AND IOWA

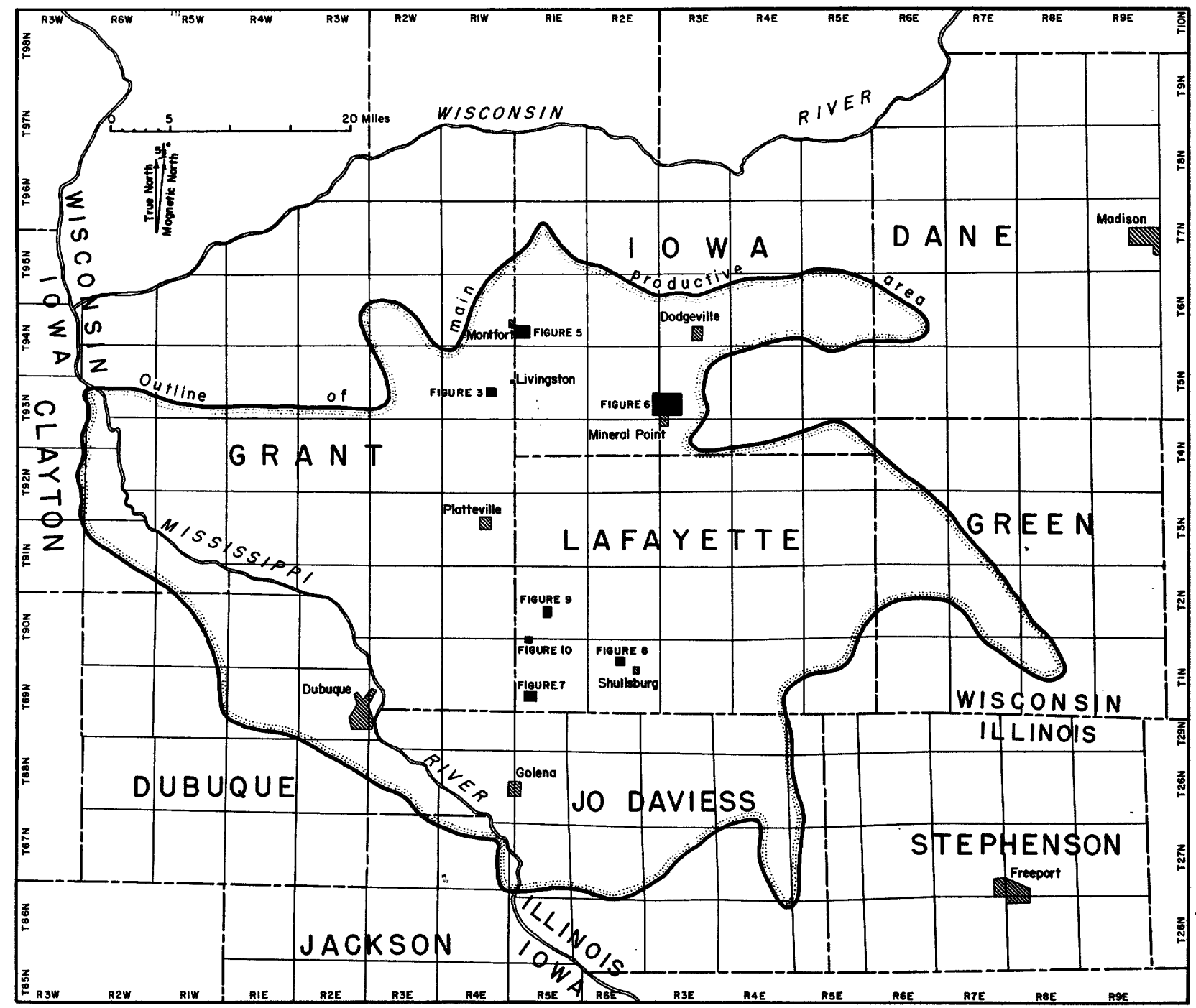

Figure 1. -Index map showing outline of main productive area of the Upper Mississippi Valley zinclead district and location of areas covered by detailed map of this report 


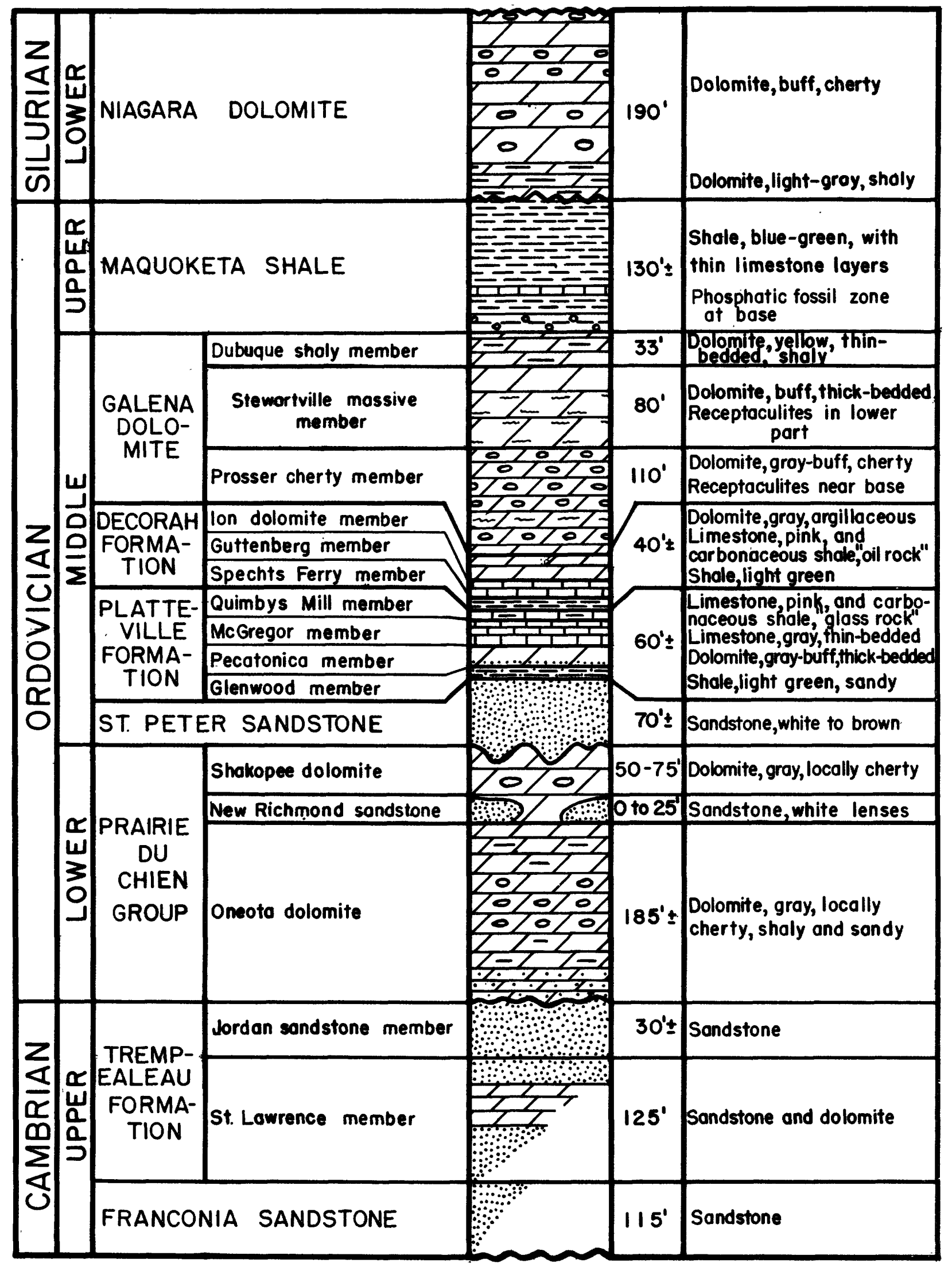

Figure 2. -Generalized stratigraphic section of the Upper Mississippi Valley zinc-lead district 
learn if the Frairie du Chien group and other formations below the principal ore-bearing strata of southwestern Wisconsin also are favorable for ore deposits and to determine the type of ore deposits, if present.

Small local deposits of sulfides in the Frairie du Chien group are widespread in its belt of outcrop to the north and northwest of the main productive area, and the lithology of the dolomitic beds suggested that these beds might contain deposits of zinc and lead ores at depth beneath the actively mined part of the district. The areas for special investigation were selected on the basis of especially favorable geologic structures or because of reported sulfides in wells that penetrated these lower strata.

Eight properties were explored by $20 \mathrm{drill}$ holes that totaled 8, 582 feet of drilling. Lean deposits of sphalerite, marcasite, and pyrite were found in the Frairie du Chien group on five properties, and also in the Franconia sandstone on one property. The location of the properties that were drilled is shown (black areas) on the index map (fig. 1).

\section{Acknowledgments}

The geological study and drilling program was under the direct supervision of A. V. Heyl, Jr. , E. J. Lyons, and A. F. Agnew. R. F. Crumpton, A. E. Flint, and J. H. Moor contributed materially to the success of the program by their assistance. W. F. Huleatt, Chief of the Fhysical Exploration Unit, was the Contracting Cfficer. D. C. Dixon was in charge of the operation of the diamond drills.

G. A. Apell of the U. S. Bureau of Mines gave valuable data and assistance on the technical details and operation of the drills.

\section{GEOLOGY}

\section{General Features}

The Upper Mississippi Valley zinc-lead district is about 100 miles south of the main area of outcrop of the pre-Cambrian shield in Wisconsin. The ore deposits are in the northern fringe of Faleozoic sedimentary rocks that overlap this shield area. The regional strike throughout most of the district is N. $85^{\circ} \mathrm{W}$., but in the western part it swings to N. $45^{\circ}$ W. The regional dip is about 17 feet per mile toward the south-southwest. The rocks of the district have been folded into broad undulations as much as 200 feet in amplitude, and are cut by numerous minor reverse, normal, bedding-plane, and shear faults that generally have displacements from 1 to 10 feet and a few faults that have large displacements.

\section{Stratigraphy}

The rocks exposed in the zinc-lead district are Silurian or older in age (fig. 2). The youngest strata, the Niagara dolomite crop out mainly along the southern and western edges of the district, but they also capa few isolated erosion outliers within it. Most of the outcrops throughout the district are Galena dolomite, but smaller and fewer exposures of the Decorah, the Flatteville, and St. Feter formations are common. The Frairie du Chien group is exposed in some of the deeper valleys and along the north and east margins of the district. The oldest rocks exposed in the area--the Franconia and Trempealeau formations of late Cambrian age--crop out only along the Wisconsin River. Rocks of the preCambrian basement have been encountered only in wells, at depths from 1,500 to 2,000 feet.

The for mations of Cambrian age consist mostly of sandstone, in part shaly and dolomitic; however, the St. Lawreme member of the Trempealeau formation, as penetrated at Montfort, Wis. , is a dolomite that contains a little quartz sand. These Cambrian strata apparently are overlain conformably by the Frairie du Chien group of Early Crdovician age.

The base of the Frairie du Chien group is a transition zone about 15 feet thick that consists of alternating sandstone, arenaceous dolomite, and dolomite beds. A persistent oolite layer is just above the transition zone and below a bed $2 \frac{1}{2}$ feet thick of algal dolomite. About 180 feet of gray to drab dolomite that weathers buff lies above the algal beds. The lower 40 feet of this dolomite is moderately thin-bedded; the upper 120 feet is thickbedded to massive. The dolomite contains a few quartz sand grains, local sand lenses and algal structures, and areas of glauconite. Vuggy areas are common. Small patches of chert occur throughout, and persistent chert bands are found toward the top of the unit. Above the massive beds are 25-50 feet of strata of variable lithology, which consists of sandstone lenses, shale, dolomite, dolomitic sandstone, chert, and cherty oolite layers. For the most part the beds are irregular and discontinuous. The most prominent feature of these strata is the large and abundant algal structures that, at least in part, cause the contact between the Prairie du Chien and overlying St. Feter sandstone to be uneven. The algal areas in particular are vuggy, although small solution cavities are common in all the dolomitic beds. Also in these algal areas is a tan to buff, compact, calcareous dolomite in even beds from 2 to 3 inches thick. The beds in places are very shaly and consist mostly of pale-green, gray, red, and maroon shale.

A disconformity of considerable relief marks the boundary between the Prairie du Chien group and the overlying St. Feter sandstone, and consequently the group varies greatly in thickness over a wide area. In the northern part of the district the maximum thickness of the Frairie du Chien is about 220 feet; in the southern part the maximum thickness is about 260 feet. The disconformity is more marked toward the south.

The St. Feter sandstone, of Middle Ordovician age, ranges from 40 to 200 feet or more in thickness. 
The lower beds of the St. Feter were deposited in the valleys within the unconformity surface. These beds consist of thin-bedded red, pink, and white, poorly-cemented sandstone with interbeds of red and green shale, dolomite, and limestone. The sand grains are well rounded and frosted but not well sorted. The upper part of the St. Feter sandstone is generally white, yellow, or brown, and consists of well-sorted, frosted, rounded quartz sand grains; it is thick bedded and may be crossbedded on a large scale.

The stratigraphy of the beds above the St. Feter sandstone is shown in figure 2; more detailed descriptions are not given here because this report is primarily concerned with the strata and mineralization below the principal ore-bearing formations.

\section{Sulfide deposits}

General characteristics. - The ore deposits that have been mined in the district are mostly in the Galena, Decorah, and Flatteville formations. The principal primary minerals are quartz (chert and other forms of silica), dolomite, sphalerite, marcasite, pyrite, galena, barite, chalcopyrite, and calcite, which were deposited throughout the district in this regular paragenetic sequence.

The ore-bearing solutions altered the host rocks within and in the immediate vicinity of the deposits by three processes: solution of the impure calcareous rocks, silicification, and dolomitization.

The ore deposits show both horizontal and vertical zoning. A northwest-trending zone passing through the east-central part of the district contains abnormally large quantities of copper, barium, and nickel. Local mines within this zone produced commercial quantities of barium and copper. On the fringes of the district, galena is the most abundant ore mineral, but in the central area, sphalerite is the most abundant ore mineral. A vertical zoning is represented by concentrations of galena near the surface, whereas sphalerite, pyrite and marcasite, quartz, dolomite, and possibly chalcopyrite are more abundant in the deeper deposits.

Sulfides in the Galena, Decorah, and Flatteville formations. - - The principal ore deposits in the Galena, Decorah, and Platteville formations can be classified according to their controlling fracture systems as reverse and bedding-plane fault type and joint type. Cre deposits of the first type are veins in faults and related fractures, which are along the flanks of folds. The vein minerals have been deposited as vein fillings along fractures and bedding planes, cavity fillings in solution and tectonic breccias, and disseminations by replacement and impregnation of favorable beds, particularly shaly layers: The joint-controlled deposits are limited to the Galena dolomite. In these deposits the chief mineral, galena, is deposited in gash veins that fill vertical joints, and in podlike bodies in favorable beds along the joints.
Sulfides in the St. Feter sandstone. - - Pyrite and marcasite are the principal sulfides in the St. Peter sandstone and in the immediately overlying, thin, sandy Glenwood shale member of the Flatteville formation. Locally, sphalerite and galena are present in small quantities. In general, the known sulfide deposits in the St. Feter sandstone are directly below large sulfide deposits in the overlying formations. The sulfides from the cement between the quartz sand grains and less commonly coat small fractures. In these areas of sulfide mineralization, secondary quartz generally has been deposited as silica cement and as crystal overgrowths on the quartz grains.

Sulfides in the Frairie du Chien group. --The Frairie du Chien group to the north of the main productive area of the district contains many small deposits of sulfides of lead, copper, iron, and zinc; and data from the Geological Survey exploration program indicate that within the main part of the district this group also contains sulfides of zinc and iron, but only traces of copper and lead. Considerable secondary silica and dolomite are present in nearly all of the mineral deposits, within the Frairie du Chien but calcite is uncommon. The known sulfide deposits in the Frairie du Chien are (1) veins or lodes along vertical joints or faults, and (2) mineralized zones of crackle and solution breccias, in places related to bedding-plane faults and shear zones. Replacements of the dolomite by pyrite and marcasite, and rarely by sphalerite, are not uncommon in the brecciated areas, and in one place sphalerite was deposited between the individual dolomite grains of a porous dolomite.

The sulfide deposits in the Frairie du Chien group at the Crow Branch, Leix, and Vinegar Hill areas lie directly beneath ore deposits in the overlying rocks. Elsewhere, though, as at the Ohlerking diggings at Highland, Wis., and the Harris and Spitzbarth properties near Mineral Foint, Wis., the deposits are not known to lie beneath sulfide deposits, although ore bodies in the overlying strata are known. nearby.

Ferhaps in the most distinctive feature of the deposits in the Frairie du Chien group is the abundance of secondary quartz. Not only does quartz (chert) replace large areas of the wall rocks, but also drusy quartz and chalcedony line vugs and fill fractures.

Sulfides in the Trempealeau and Franconia formations. --The Trempealeau and Franconia formations in the Upper Mississippi district are exposed only in the deepest valleys along the Wis consin and Mississippi Rivers north of main productive area of the district, and only a very few of the known lead and zinc deposits are in them. In two of these deposits the Lansing lead mine and the lead prospect near Dresbach, Minn. , (Winchell, 1884, p. 258)--galena is in veins along faults. Sphalerite, pyrite, and marcasite were found in the Franconia sandstone on the Leix property at Montforth, Wis. , 
by the Geological'Survey drilling. The sulfides in these shaly sandstone beds occur between the quartz sand grains and are similar to the sulfides in the St: Feter sandstone deposits.

\section{EXPLORATORY WORK BY THE GEOLOGICAL SURVEY}

\section{Froblems of drilling}

The exploratory program of the Geological Survey consisted of both diamond and churn drilling. The churn drilling was technically more successful and considerably less expensive than diamond drilling.

Diamond drilling. --Three types of rocks-sandstone, soft plastic shales, and porous cherts-caused the chief difficulties in drilling. The pounding of the core barrel and rods, plus the current of the return water, removed large quantities of sand from the drilling hole walls in the parts of the St. Feter sandstone that consist of well-rounded grains of very loosely cemented quartz sand. As long as the water return was strong, this sand was washed out of the drill hole. If the return flow of water stopped, either because of mechanical difficulties or because of cutting a permeable zone or fracture, the sand dropped to the bottom of the hole and quickly settled around the barrel and bit, completely binding it to the wall. In most cases sufficient water pressure could not be obtained to wash out the sand if it was wedged above the bit; if this sand was packed particularly tight, reverse drilling was impossible also. A very high-pressure flow of water and very careful checking of the water pressure by use of a gage on the drill was helpful. The pump that fed the water into the drill was always located nearby so that water pressure could be regulated quickly. The use of aquagel mud was helpful in some holes.

The soft plastic shaies in the Frairie du Chien group, and in the basal part of the St. Feter sandstone, where it is thick, were drilled successfully by casing or cementing the hole immediately after drilling stopped at the end of the day before the hole could fill with shale. The use of small rather than large amounts of water helped decrease the swelling and heaving of the shale.

The cherts, where highly fractured and several feet thick, were difficult to drill. In some places several bits were worn out after penetrating only a few feet of chert, and therefore drilling was usually expensive.

An obvious advantage of diamond drilling is that cores provide considerably more information concerning lithology and mineral occurrence than do churn-drill cuttings. A disadvantage, however, is the poor recovery of core in highly fractured mineralized rocks; also, at best, the recovery of sludges was intermittent. NX bits gave the best core recovery.

The diamond drilling program has shown that successful penetration of the strata of this area requires extreme care in drilling sedimentary rocks. Moreover, a trained exploration engineer, rather than a geologist, should be assigned to a diamond-drilling project to manage technical problems. He should have full authority to make decisions as to the methods and time of casing, cementing, reaming, reduction of bit size, and abandonment of the drill hole.

Churn drilling--Fewer mechanical difficulties were encountered in churn drilling than in diamond drilling. The loosely consolidated layers of the St. Feter sandstone were drilled without much difficulty. Cherty portions of the dolomites caused considerable wearing of the bits, but because the cherts are brittle they were more easily shattered and drilled by this method. Inclined fractures, particularly where the walls were indurated by silica, caused difficulties; the bit tended to follow the fracture and to become wedged. In one drill hole, blasting was necessary to shatter the hardened footwall of a fracture so that this wall could be penetrated by the drill bit.

The soft plastic shale that made core drilling difficult also constituted the main problem in churn drilling. Very slow drilling under light weight and a short stroke were helpful in penetrating these beds. Some holes through the shale beds had to be reamed and cased immediately after drilling, to prevent caving. Concentric casing was set in one drill hole where a second shale bed was cut below the first casing.

The large diameter of the churn-drill holes and the more consistent recovery of the cutting made the samples of mineralized rock more representative of the true rock content than the samples obtained by diamond drilling. However, the churn-drill cuttings do not retain nearly as many of the stratigraphic and ore-deposit characteristics; and self-salting in some of the drill holes made casing necessary.

The churn drilling proceeded much more rapidly and needed less supervision than the diamond drilling. This saving in manpower lowered considerably the total cost of exploration.

\section{Results}

Eight properties were drilled during the investigation. Five were selected because of known ore deposits in the Galena, Decorah, and Platteville formations and because of favorable geologic structures. The other three properties (Leix, Spitzbarth, and Harris) were drilled to check reports that wells had cut some sphalerite mineralization in the Frairie du Chien group.

In the southern part of the Wisconsin district, the unconformity separating the St. Feter sandstone from the underlying Frairie du Chien group cuts so deeply into the Prairie du Chien on the James and Raisbeck properties, that only a small thickness of the dolomite remains. On the other properties the dolomite has not been thinned by erosion, and hence it is sufficiently thick to form the host rock for large lead and zinc deposits. On five of the properties drilled--Crow Branch, Leix, Vinegar Hill, Spitzbarth, and Harris--lean 


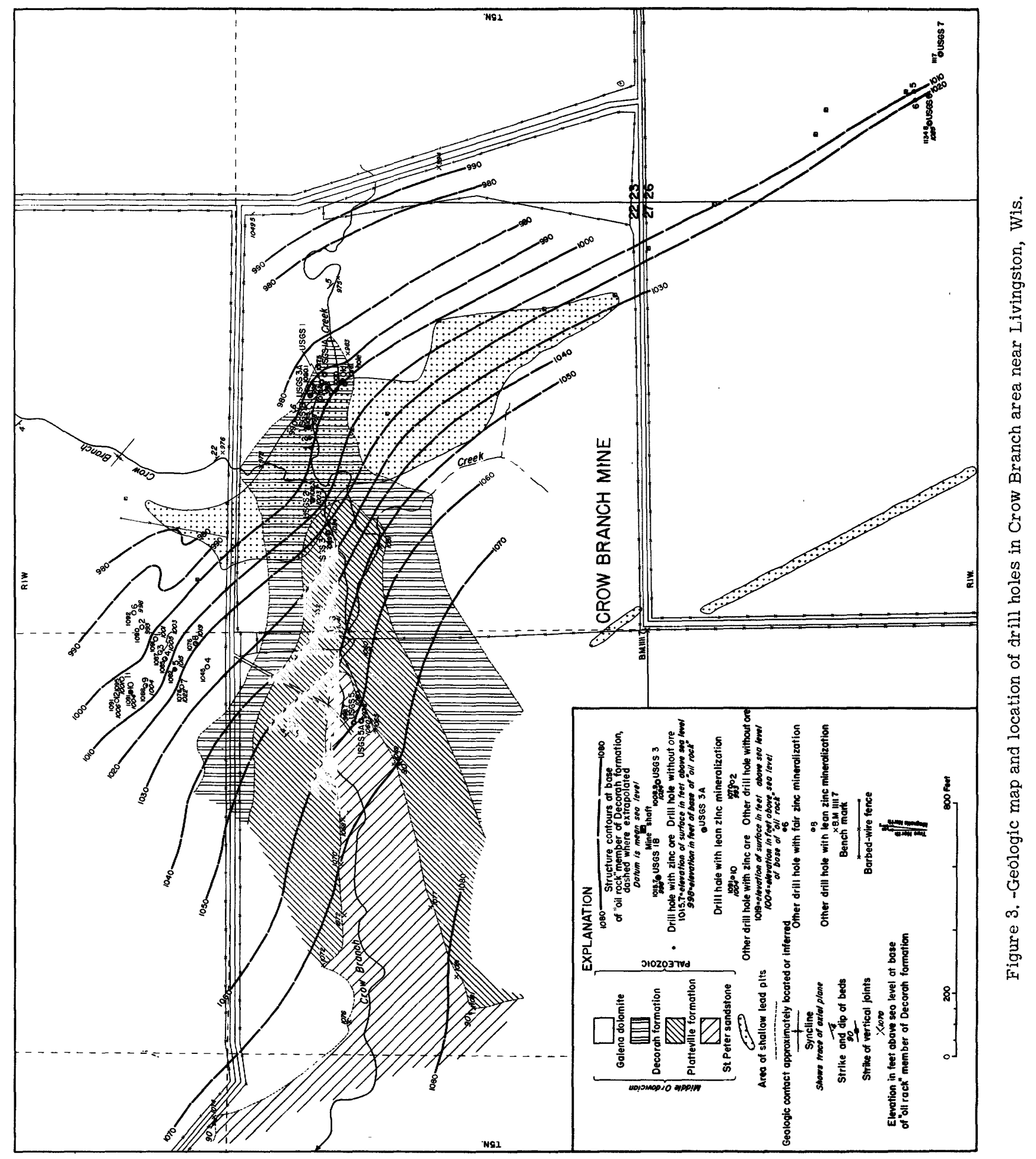


sphalerite, marcasite, and pyrite deposits were found in the Frairie du Chien. On the Kennedy property pyrite and marcasite were found in notable quantities in this formation. Sphalerite and pyrite were found also in the Franconia sandstone at the Leix property, where drilling penetrated a considerable thickness of the Cambrian beds. As was expected, zinc and lead sulfides in considerable quantities were found in the Galena, Decorah, and Flatteville strata in the Crow Branch, Kennedy, Leix, and Vinegar Hill areas. Logs of the holes drilled on these properties are listed at the end of the report.

Crow Branch area. --The major structural feature in the Crow Branch area (fig. 3) is a northwest-trending sycline that has an amplitude of about 100 feet and is assymetric with a steeper south- west limb. The drill holes showed that the fold has the same magnitude at the top of the Cambrian beds as it does in the overlying Platteville and Decorah strata (fig. 4).

The Crow Branch ore body lies along the lower part of the southwest steeper limb of the major syncline, and is known to be at least 3,100 feet in length and as much as 300 feet in width. The largest area of shallow lead pits (fig. 3 ) indicates the general lateral extent of the ore body where it is partly eroded or at shallow depth in Crow Branch Creek valley. The ore occurs in all the beds from the Prosser thirty member of the Galena dolomite downward into the McGregor limestone member of the Flatteville formation. The ore body was mined for lead ore during the nineteenth century, and while in operation, was described by several geologists

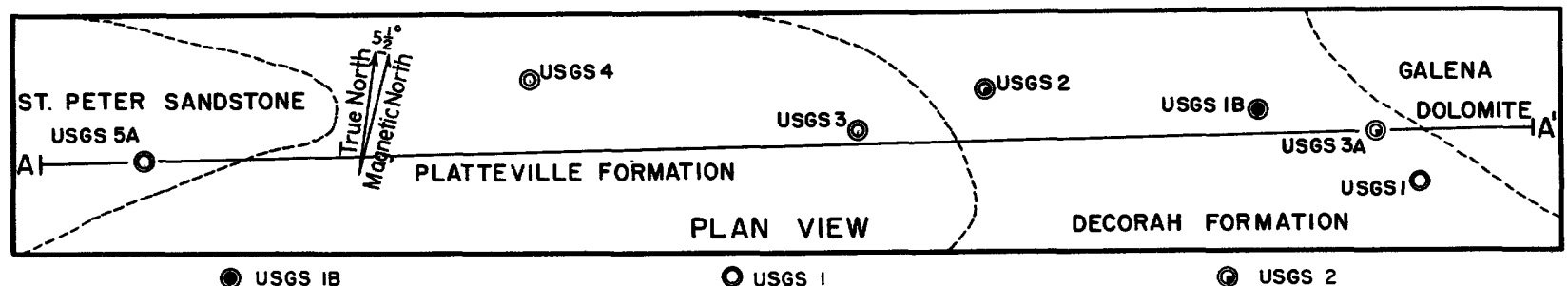

Drill hole with zinc ore

Shows elevotion of surfoce in feet obove sea level Shows elevotion of surfoce in feet obove sea level shows elevotion of surfoce in feet obove seo level

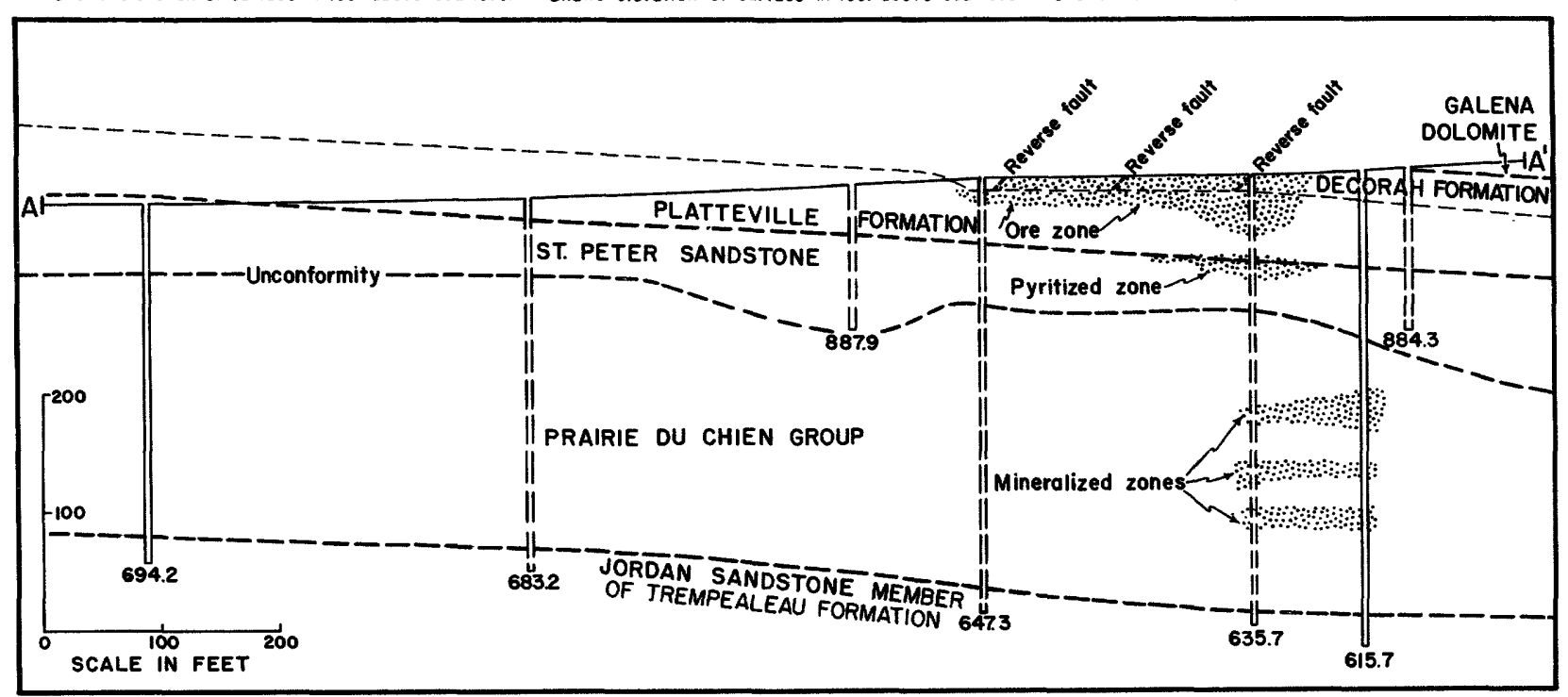

\section{CROSS SECTION}

Figure 4. -Flan view and geologic map and cross section in the northwestern part of Crow Branch area (fig. 3) 
(Fercival 1856, pp. 34-36, 47-48, 61-62; Hall and Whitn эy, 1862, pp. 361-364; Chamberlin 1882, p. 481). It is controlled by several northwest-trending, southwest-dipping reverse faults (fig. 4) and associated bedding-plane faults.

The Crow Branch area was explored by 10 Geological Survey drill holes, 3 of which (USGS 1,3 , and 5) bottomed above the Frairie du Chien group, owing to mechanical difficulties encountered by the diamond drill. Seven of the Geological Survey drill holes are located along a line trending at nearly right angles to the trend of the major syncline in order to explore in the Frairie du Chien group for an extension at depth of the ore in the Galena, Decorah, and Flatteville formations (fig. 4). The drilling indicated that the southwest-dipping fault system that controls the ore body above the St. Feter sandstone apparently does not extend below the Platteville formation. However, three mineralized zones were found that contain sphalerite, pyrite, and marcasite in the beds of the Frairie du Chien. These zones lie beneath and toward the northeast of the ore body in the Galena, Flatteville, and Decorah formations. The zones are apparently in the more brittle dolomite beds of the Prairie du Chien which have been fractured into a crackle breccia during the tectonic deformation that produced the folds and the over-lying unconnected faults. The undulations in the beds in the upper ore zone (fig. 4) at the top of the Flatteville formation are the result of solution thinning by the ore solutions and some faulting in these beds. Disregarding these local undulations, the dip of the lower beds closely corresponds to that of the upper beds. In one drill hole (USGS 1B) a pyritized zone was found that contains a little sphalerite and galena. The two drill holes (fig. 3, USGS 6 and 7) were drilled at the southeast end of the Crow Branch ore body to see if the zinc-bearing zones of the Frairie du Chien extended along the trend of the ore body. No sphalerite was found, but instead considerable quantities of pyrite and marcasite were present.

Leix property. - The single churn-drill hole on the Leix property (fig. 5) was put down to check reports of sphalerite in the Frairie du Chien group in the well drilled 60 feet to the south, in the middle of the railroad right-of-way, by the Chicago \& North Western Railway in 1910.

In the U. S. Geological Survey drill holes (USGS 1), a little honey-yellow sphalerite was found in the lower part of the Frairie du Chien group at a depth of from 395 to 405 feet and the sphalerite is in the pores between the dolomite grains of the rock.

Disseminated sphalerite ore was cut in the Guttenberg limestone member of the Decorah formation, at 145-150 feet in depth. This ore is 900 feet to the east of, and probably is on the extension of, the easterly heading of the abandoned C. F. David mine; its location therefore suggests that an unmined part of the ore body extends at least this far toward the east.
A third mineralized zone that contains considerable pyrite and a little sphalerite was found in the upper part of the Franconia sandstone, where the sulfides occur as cement between the quartz sand grains and are disseminated in the glauconitic green shales.

Farmley Harris property. --A well on the Harris property (fig. 6) that was deepened in 1949 struck considerable sphalerite and marcasite in the uppermost beds of the Frairie du Chien group. The first 2 feet of the deepened well were in greenish sandy shale at a depth of 170 to 172 feet and averaged 0.35 percent zinc and 3.55 percent iron (analyst, Frank Walther, Platteville, Wis.)--the iron in the form of pyrite and marcasite. The nearby Geological Survey hole ( 20 feet west of the well) drilled subsequently, found slightly smaller quantities of sphalerite, pyrite, and marcasite at about the same depth.

Spitzbarth property. --A well drilled in 1900 on the Spitzbarth property (fig. 6) was reported to have penetrated sphalerite in the upper beds of the Frairie du Chien group. A check hole was drilled by the Geological Survey within 20 feet of the old well; some sphalerite, pyrite, and marcasite were found in those beds at a depth of 100 to 105 feet. This sphalerite was in large crystals that apparently lined cavities in the rock, or replaced it.

Kennedy mine property. --The Kennedy mine property (fig. 7) contains the large abandoned Kennedy mine, which is in one of the important northwest-trending ore bodies in the south-central part of the district. The ore body lies along the axial area of one of the larger northwest-trending synclines. Six holes were drilled along a line bearing southwest, at right angles to the general structural trend. Holes 3 and $3 \mathrm{~A}$ were not completed, owing to diamond drilling difficulties, but hole $3 B$ was completed very near the other two, by churn drilling. Hole 1, in the central area of the ore body, is between the two reverse fault zones that bound the ore body. This drill hole cut lean zinc and iron sulfide deposits in the beds above the St. Feter sandstone, and similar quantities of pyrite and marcasite in the basal part of the St. Feter sandstone and at two horizons in the lower part of the Prairie da Chien group. In the middle of the Frairie du Chien, from 355 to 368 feet in depth, the rock was entirely replaced by silica in the form of chert, drusy quartz, and jasperoid. This silicification was to a lesser extent in drill hole 2 , at the western edge of the ore body, but not in the holes still farther southwestward.

Hole 2 penetrated 15 feet of mineable ore in the lower beds of the Decorah formation, and indicates that some unmined ore remains in the mine walls. Although no zine was found in the Prairie du Chien beds, the considerable quantities of iron sulfide and the intense silicification indicate that mineralizing solutions passed through these beds. 


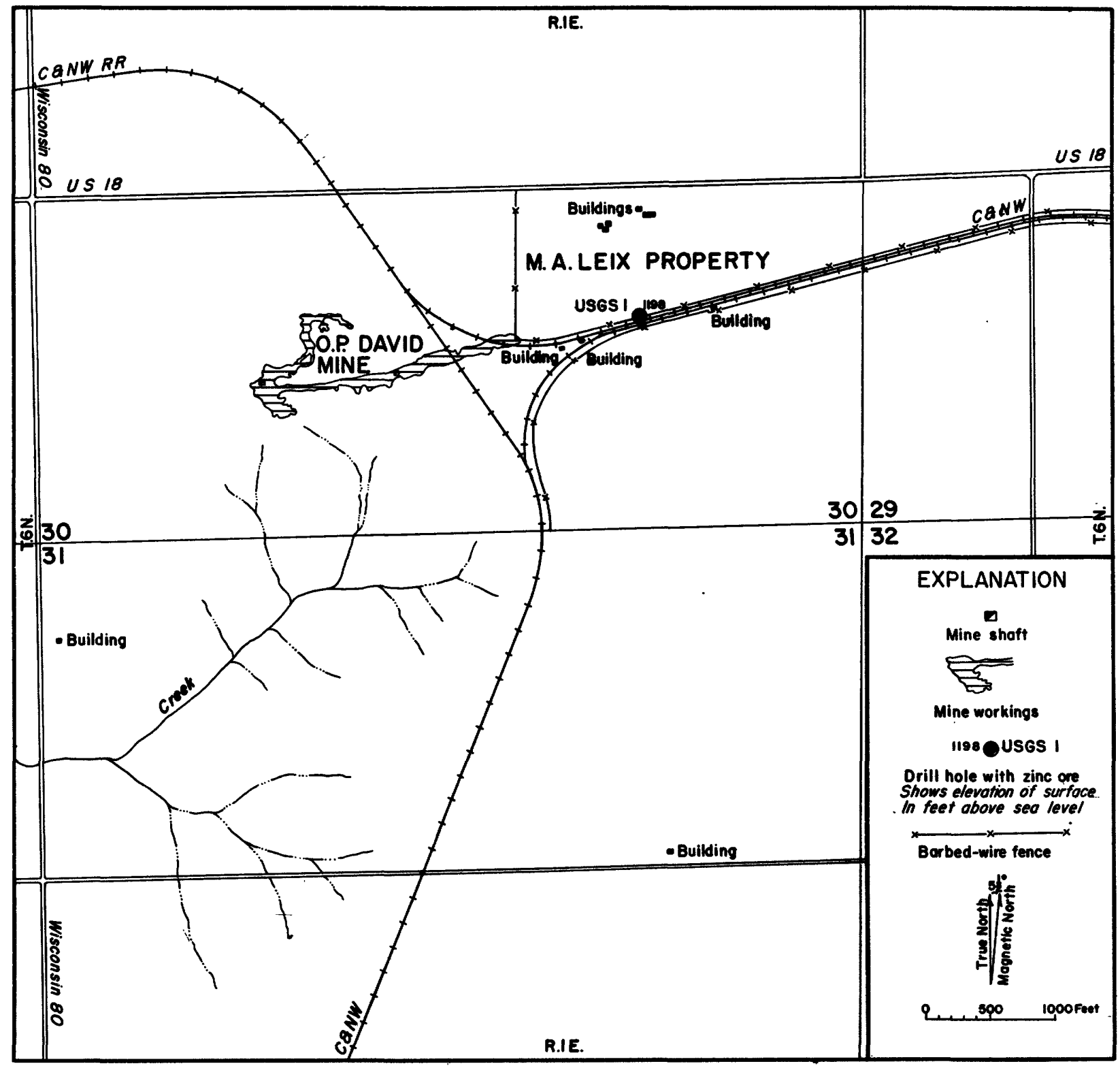

Compiled by U.S. Geological Survey from

mine map by New Jersey Zinc Co.,

oerial photos and original surveys, 1950

Figure 5. -Map showing workings of C. F. David mine and location of drill holes on Leix property near Montfort, Wis. 


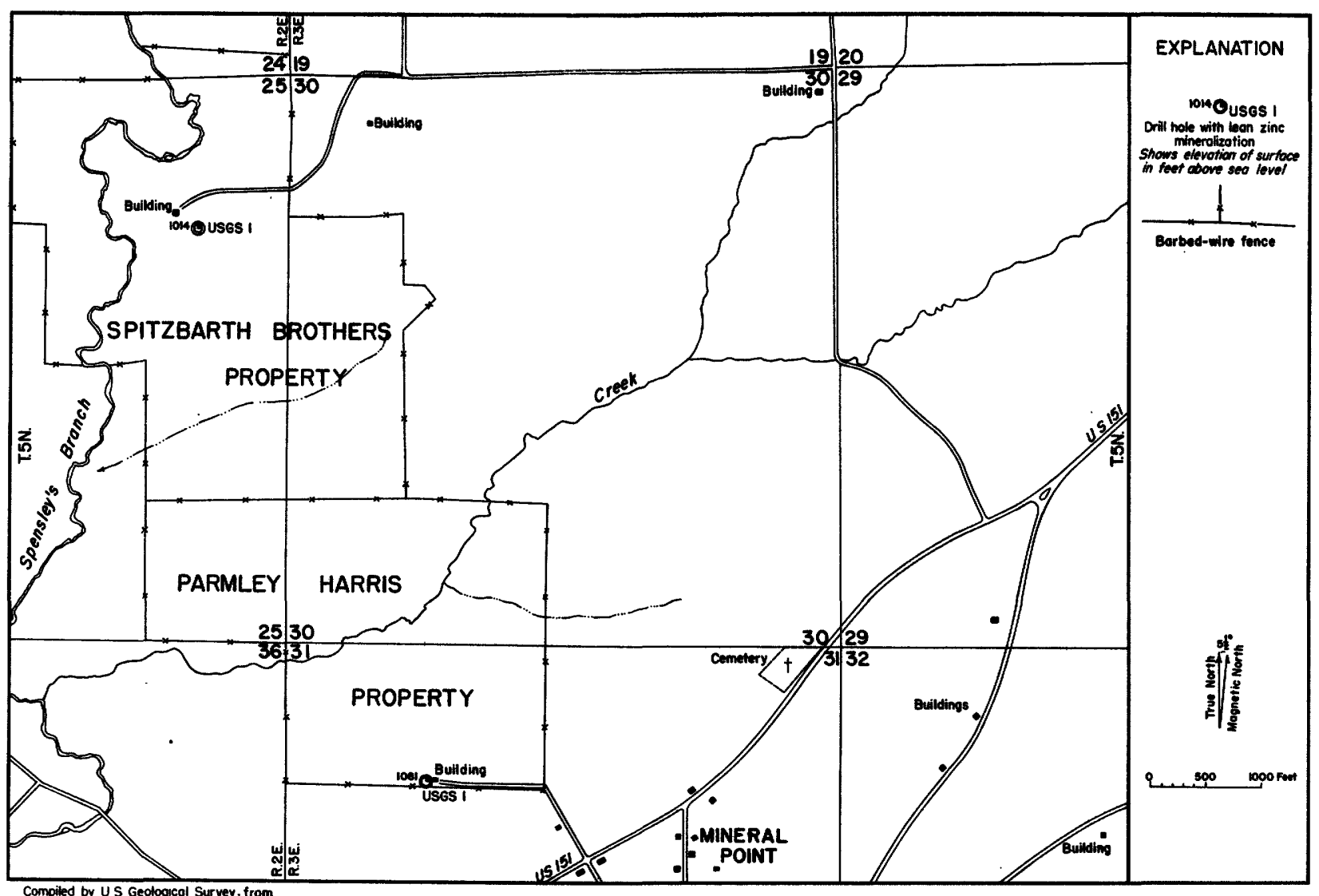

Compiled by US Geological Survey. from
oerial photos ond original Surveys, 1950

Figure 6. -Map showing location of drill holes on Spitzbarth and Harris properties near Mineral Foint, Wis.

The unconformity at the base of the St. Feter sandstone is fairly well marked here, and the lithology of the Frairie du Chien strata changes rapidly laterally. In some places, as in hole 1 , the rock is nearly all dolomite; in others, as in hole 4, it is largely red and green shales interbedded with dolomite.

James mine area. --One diamond drill hole was completed in the James mine area (Thomas Doyle property) near Shullsburg, Wis. (fig. 8). This drill hole penetrated an unusually great thickness (276 feet) of St. Peter sandstone and a small thickness of Frairie du Chien group so additional contemplated drill holes were not started. In addition to being thicker than normal the St. Feter sandstone in this drill hole has an unuslal lithology, particularly the lower 110 feet that consist of thin beds of red, brown, yellow, and white sandstones interbedded with red and green shales, and a little limestone and dolomite. The exact stratigraphic age and relationships of these lower beds are not known. They are strongly sheared, slickensided, and full of small drag folds.

\section{Meekers Grove area. --Three churn-drill} holes were put down on the Raisbeck property just south of Meekers Grove, Wis. (fig. 9). These holes are located on a line bearing north-northeast across the steeper north limb of a major anticline of about 200 feet amplitude that trends east. (Heyl and others, 1945). All of these holes cut very thick St. Peter sandstone including considerable thicknesses of the unusual red and green shale and sandstone beds similar to those in the James mine drill hole. The only sulfides found in these holes were 


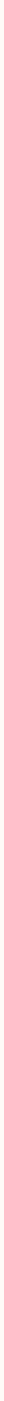

Figure 7. -Map showing location of drill holes on Kennedy mine property near Hazel Green, Wis.

considerable pyrite and a little galena in the upper part of the St. Feter sandstone in holes 1 and 2, and abundant iron sulfide in the Galena and Decorah formation in hole 3 .

Vinegar Hill roaster property. --Although the U. S. Geological Survey drilling in the southcentral part of the district has been unfavorable, owing to the unconformity at the top of the Frairie du Chien group that here cuts out most of this group in several known places, one hole was drilled on the property of the Vinegar Hill Zinc Co. (fig. 10) where previous drilling by that company had indicated that normal dolomitic Frairie du Chein strata were present: Also, older drilling had located an ore body in the Galena and Decorah beds along an east-trending syncline.
The Geological Survey drill hole was placed within the area of this ore body, and considerable iron and zinc sulfides were penetrated in the Galena and Decorah formations. Fractured dolomite of the Frairie du Chien group, in which a little coarsely crystalline sphalerite and marcasite coated the fracture walls, was cut from depths of 445 to 455 . A little sphalerite was found along the uppermost part of the sandstone of Cambrian age.

\section{Conclusions}

Although no minable ore was found in the beds beneath the Flatteville formation, the Geological Survey drilling program showed that the dolomite beds of the Prairie du Chien group, where present throughout the mining district, are favorable 


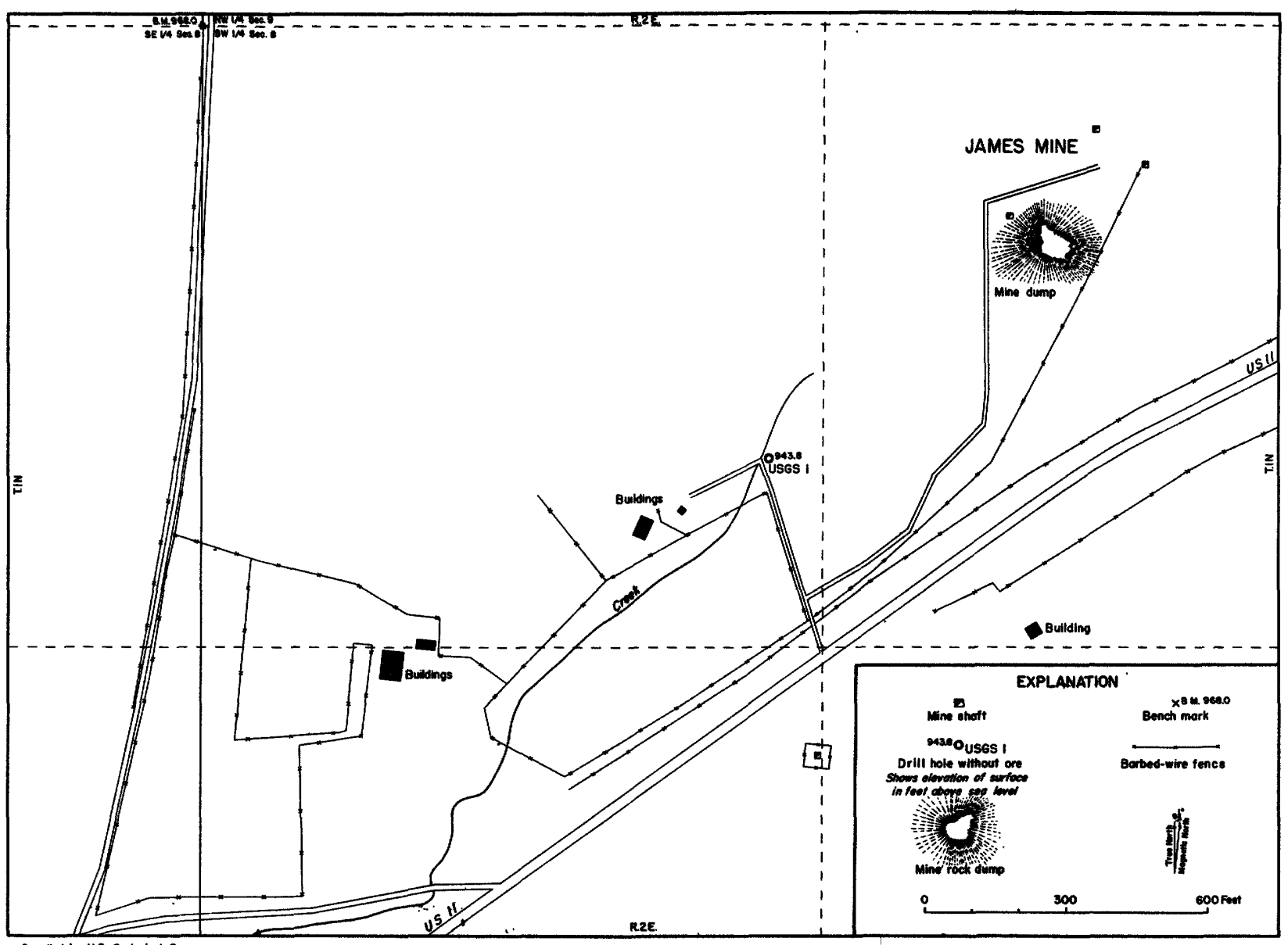

Compiled by U.S. Goologicol Survery
from oerial photos ond originem

trom arrial phose, 1950

Figure 8. -Map showing location of drill holes on James mine property near Shullsburg, Wis.

at several horizons for sulfide deposits. To date the sulfide deposits in the Prairie du Chien are all very low in grade and consist mainly of sphalerite, marcasite, and pyrite; and they are unlike the galena and chalcopyrite deposits that are prevalent in these rocks to the north of the main productive area.

The northern part of the main productive area of the mining district is considered more favorable for the occurrence of ore deposits in the Frairie du Chien group than the southern part. The drilling indicates that in many places within the southern part of the district the Prairie du Chien is considerably thinned by pre-st. Feter erosion, now represented by the unconformity separating the St. Feter sandstone and the underlying Frairie du Chien. In the northern part of the mining district on the other hand, the Frairie du
Chien is 200 feet or more in thickness, except locally where erosion channels formed by pre-St. Feter erosion are known. Because the Frairie du Chien group is generally much thicker in the northern part of the district, and hence is here represented by a greater thickness of dolomite, the writers believe that this area is more favorable for the occurrence of zinc-lead deposits of possible commercial importance.

In some places, as in the Crow Branch, Kennedy, Leix, and Vinegar Hill roaster areas, the deeper sulfide deposits lie almost directly beneath the deposits in the Galena, Decorah, and Platteville formations.

In the areas drilled, the sulfides in the Prairie du Chien group were deposited in certain more brittle or soluble dolomite beds in which cavities were 


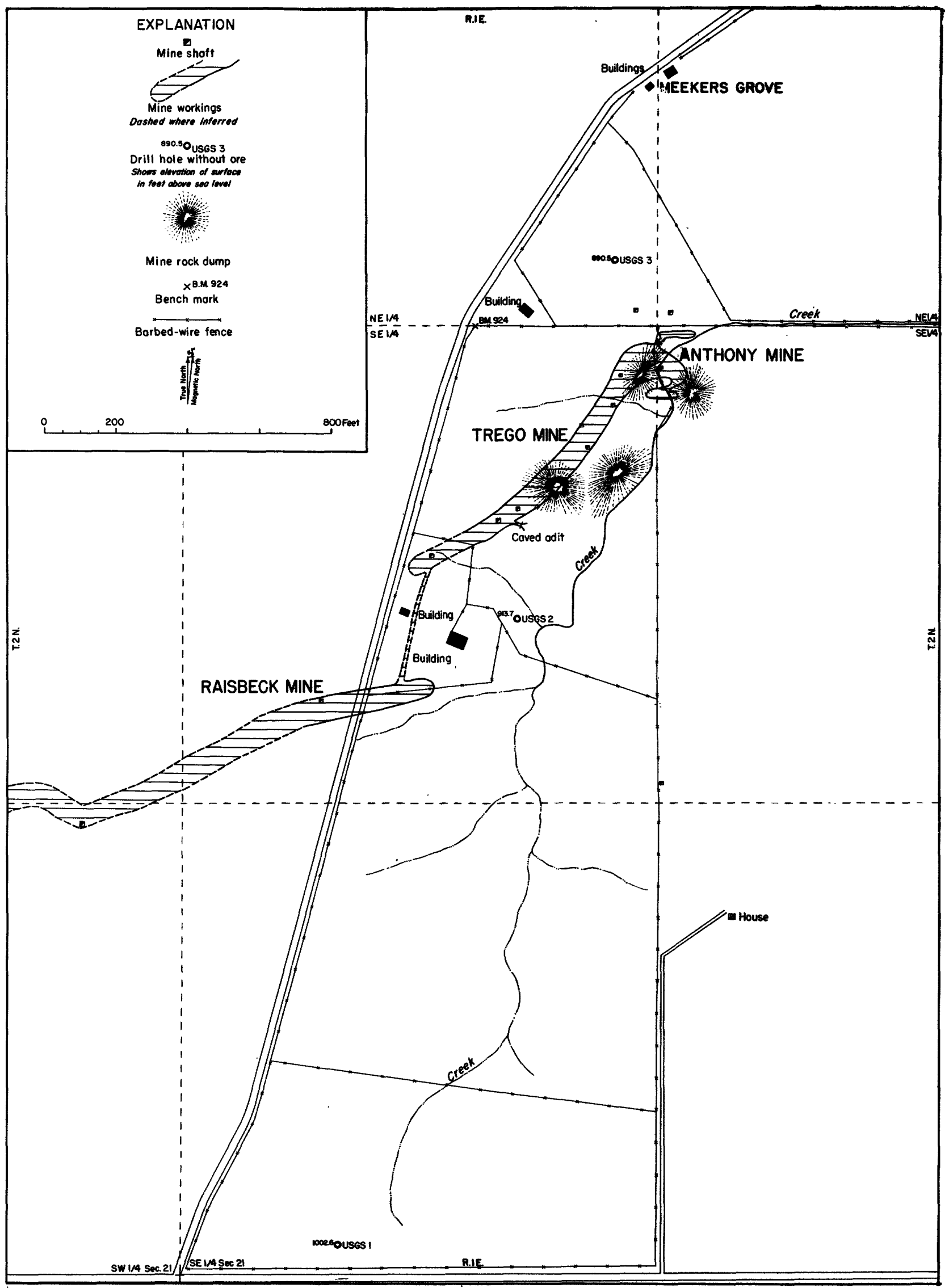

Compled by U.S. Geological Survey from mine maps,

aerial pholos and origmol surveys, 1950

Figure 9. -Map showing location of drill holes on Raisbeck property, Meekers Grove area, Wis. 


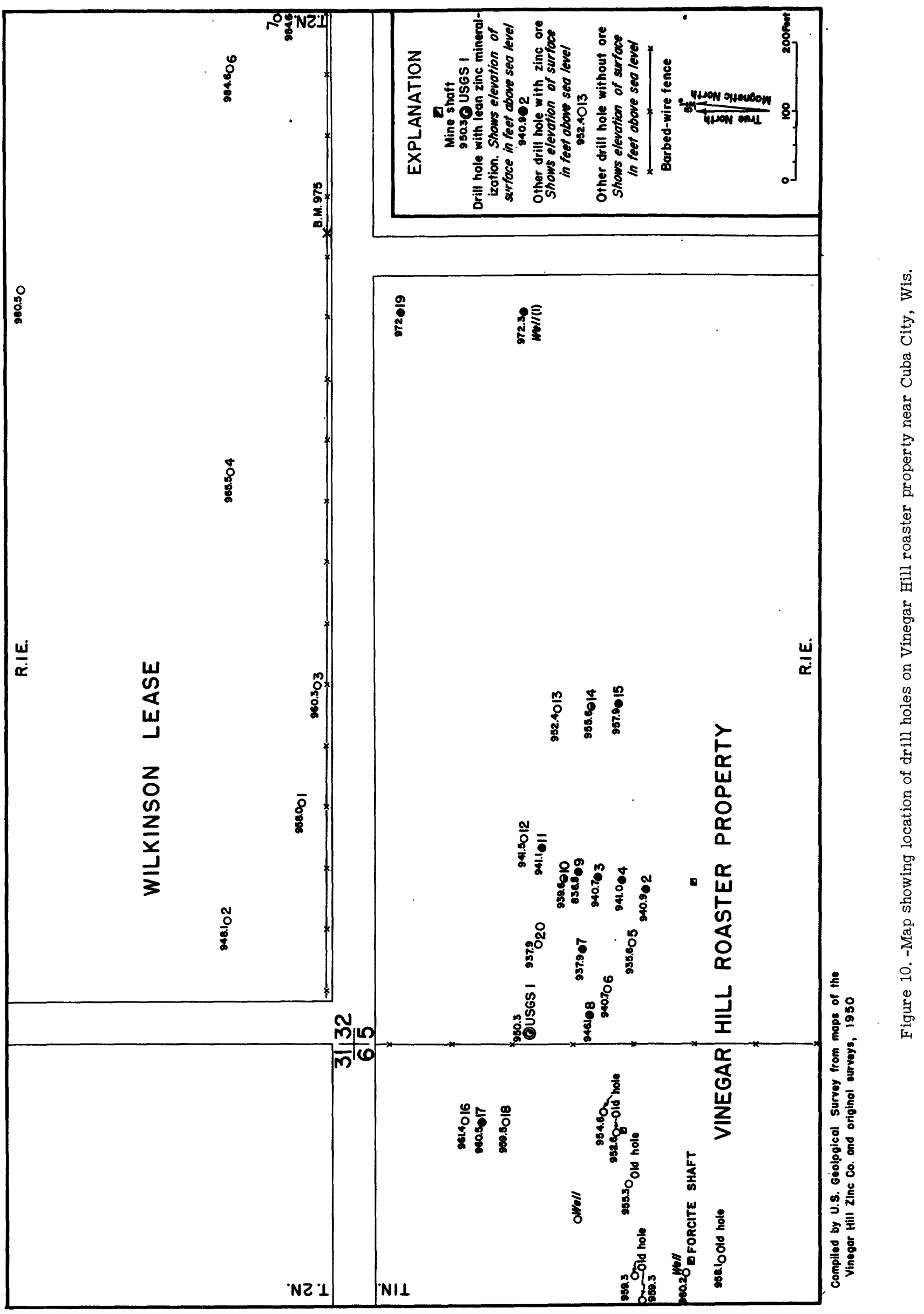


formed by brecciation or solution. The sulfides are in laterally extending brecciated or vuggy zones rather than along distinct vertical fractures or replacement areas. Abundant silica and dolomite are deposited with the sulfides. In many respects this type of sulfide deposit is similar to that found in the Joplin, Mo., mining district.

At Crow Branch the drilling indicated that the large folds, at least, are not limited to the the Middle Ordovician beds but are equally well developed in the underlying formations.
The drill hole that penetrated a considerable thickness of the upper part of the Cambrian strata on the Leix property showed that some of these beds are also favorable for sulfide deposits.

A by-product result of the drilling program of the Frairie du Chien group was the discovery of additional ore in the Galena, Decorah and Flatteville formations on three of these properties, the Crow Branch, Leix, and Kennedy. These ore discoveries are small contributions to the known ore reserves of the Wisconsin district.

\section{SELECTED BIFII IOGRAFHY}

Bain, H. F., 1906, Zinc and lead deposits of the Upper Mississippi Valley: U. S. Geological Survey Bull. 294, p. 3.

Chamberlin, T. C. , 1882, Geology of Wisconsin: Wisconsin Geol. Survey, vcl. 4, pp. 481, 511-517, 554-560.

Hall, James, and Whitney, J. D. , 1862, Report on the Geological Survey of the State of Wisconsin: Wisconsin Geol. Survey, vol. 1, pp. 361-364, 405-413.

Heyl, A. V., Jr., Agnew, A. F., and Behre, C. H., Jr., 1945, Zinc deposits of the Meekers Grove (Jenkinsville) area of the Wisconsin zinc-lead district: U. S. Geol. Survey preliminary rept., $6 \mathrm{pp}$.

Heyl, A. V., Jr., Agnew, A. F., Behre, C. H., Jr., and Lyons, E. J., 1848, Zinc-lead deposits of the Hazel Green-Shullsburg area, Lafayette and Grant Counties, Wisconsin: U. S. Geol. Survey Strategic Minerals Invs. Frelim. Rept. 3-216, $11 \mathrm{pp.}$

Heyl, A. V., Jr., Lyons, E. J., and Agnew, A. F. . 19.48, Geologic structure map of the Foto lead-zinc area, Grant County, Wisconsin: U. S. Geol. Survey Strategic Minerals Invs. Frelim. Map 3-221.

Heyl, A. V., Jr., Lyons, E. J., and Thieler, J. J. , 1950, Lead-zinc deposits cf the Beetown area, Grant County, Wis.: U. S. Geol. Survey Minerals Invs. --Field Studies (In preparation).

Jenney, W. F. , 1894, The lead and zinc deposits of the Mississippi Valley: Am. Inst. Min. Eng. Trans., vol. 22 , pp. $211-212$.

Fercival, J. G., 1855, Annual report of the Geological Survey of Wisconsin, Midison, p. 66.

- 1856, 2d annual report of the Geological Survey of Wisconsin, Madison, pp. 34-36, 47-48, $59,61-63$.

Thwaites, R. G. , 1895, Notes on early lead mining in the Fever (Galena) River region: Wisconsin Hist. Coll. vol. 13 , p. 272 .

Winchell, N. H. , 1884, Geology of Minnesota, in The Geological and natural history survey of Minnesota, Minneapolis, vol. 1, p. 258. 


\section{DESCRIFTIVE RECORDS OF DRILL HOLES}

All drill holes are at $90^{\circ}$ inclination. All percentages in long descriptions are estimates in terms of the metal content, $i$. e. galena percent means 1 percent lead in the sample.

\section{CROW BRANCH AREA}

\section{Crow Branch no. 1 (Diamond Drill Log)}

Location: $1281 \mathrm{ft} \mathrm{N}: 37^{\circ} 15^{\prime}$ E. of southeast corner sec. $22, T$. $5 \mathrm{~N} .$, R. $1 \mathrm{~W}$.

Date begun: $7 / 2 / 48$

Date completed: $7 / 5 / 49$

Water table: not reached Elevation collar: $1016.3 \mathrm{ft}$

Total depth: $132+\mathrm{ft}$

Driller: Frank Balcar

\begin{tabular}{l|r|l|l}
\hline \multicolumn{2}{c|}{ Footage } & \multicolumn{1}{|c}{ Unit } & \multicolumn{1}{c}{ Description } \\
\hline From & To & & \\
\hline & 5.4 & & Surficial, residual. \\
5.4 & 7.2 & Decorah-(Ion) & Limestone, gray; dolomite, buff. \\
7.2 & 20.2 & Decorah-(Guttenberg) & Limestone, buff; shale, brown, trace pyrite. \\
20.2 & 25.4 & Decorah-(Spechts Ferry) & Limestone, gray, argillaceous. \\
25.4 & 28.6 & Flatteville-(2uimbys Mill) & Limestone, buff; shale, brown. \\
28.6 & 60.6 & Flatteville-(McGregor) & Limestone, gray. \\
60.6 & 79.4 & Flatteville-(Fecatonica) & Limestone, buff. \\
79.4 & 81.6 & Flatteville-(Glenwood) & Shale, green, sandy; trace pyrite. \\
81.6 & $132 \pm$ & St. Feter & Sandstone, trace pyrite. \\
\hline
\end{tabular}

Crow Branch no. 1B

Location: $1236 \mathrm{ft} \mathrm{N.} 21^{\circ} 30^{\prime}$ E. of southeast corner sec. 22, T. $5 \mathrm{~N} .$, R. $1 \mathrm{~W}$.

Date begun: $9 / 6 / 49$

Date completed: $9 / 13 / 49$

Water table struck: $8 \mathrm{ft}$ Elevation collar: $1015.7 \mathrm{ft}$

Total depth: $380 \mathrm{ft}$

Driller: Gille Bros.

Churn Drill Log

\begin{tabular}{|c|c|c|c|}
\hline \multicolumn{2}{|c|}{ Footage } & \multirow[b]{2}{*}{ Formation } & \multirow[b]{2}{*}{ Description } \\
\hline From & To & & \\
\hline 0 & 9 & Decorah-(Ion) & $\begin{array}{l}\text { Dolomite, gray and blue, mottled; littlesphalerite, pyrite, } \\
\text { marcasite, barite, calcite and trace of galena. }\end{array}$ \\
\hline 9 & 17 & Decorah-(Guttenberg) & Dolomite, pink, dense. Mineralization same. \\
\hline 17 & 20 & Decorah-(Spechts Ferry) & $\begin{array}{l}\text { Limestone, gray, argillaceous, fossiliferous; with phosphate } \\
\text { nodules; mineralization same. }\end{array}$ \\
\hline 20 & 23 & Flatteville-(Quimbys Mill) & Dolomite, gray-brown, dense; mineralization same. \\
\hline 23 & 52 & Flatteville-(McGregor) & $\begin{array}{l}\text { Dolomite, buff and gray; mineralization same but decreasing } \\
\text { with depth. }\end{array}$ \\
\hline 52 & 71 & Flatteville-(Fecatonica) & $\begin{array}{l}\text { Dolomite, bluish-gray, argillaceous; marcasite, pyrite, } \\
\text { sphalerite; phosphate nodules } 68-70 \text {. }\end{array}$ \\
\hline 71 & 73 & Flatteville-(Glenwood) & $\begin{array}{l}\text { Shale, green, sandy, with pyrite, marcasite, and phosphate } \\
\text { nodules; trace barite. }\end{array}$ \\
\hline 73 & 115 & St. Feter & $\begin{array}{l}\text { Sandstone, medium-large grained; sphalerite } 75-95 \text {; pyrite } \\
\text { and marcasite; little barite; trace galena } 80-85 .\end{array}$ \\
\hline 115 & 200 & Frairie du Chien & $\begin{array}{l}\text { Dolomite, light-gray to buff; trace pyrite and marcasite; gray } \\
\text { green shale; oolite } 125-130,135-140,145,-170 ; \text { glauconite } \\
125-130.195-200 ; \text { cherty, ittle areen shale. }\end{array}$ \\
\hline 200 & 370 & Frairie du Chien & $\begin{array}{l}\text { Dolomite, same; cherty; sphalerite } 200-210 \\
\text { and marcasite; trace chalcopyrite } 250-255 ; \frac{220-340,}{\text { several sandy }} \\
\text { zones; trace areen shale trace qlauconite. }\end{array}$ \\
\hline 370 & 380 & Trempealeau-(Jordan) & $\begin{array}{l}\text { Sandstone, colorless, rounded grains; trace pyrite and } \\
\text { marcasite. }\end{array}$ \\
\hline
\end{tabular}


Analyses $\underline{2}$

\begin{tabular}{|c|c|c|c|c|}
\hline \multicolumn{2}{|c|}{ Feet } & \multirow[b]{2}{*}{$\mathrm{Zn}$} & \multirow[b]{2}{*}{$\mathrm{Fe}$} & \multirow[b]{2}{*}{$\mathrm{Fb}$} \\
\hline From & To & & & \\
\hline $\begin{array}{c}0 \\
15 \\
20 \\
25 \\
30 \\
35 \\
40 \\
45 \\
47.5 \\
50 \\
52.5 \\
55 \\
57.5 \\
60 \\
62.5 \\
65 \\
67.5 \\
70 \\
72.5 \\
75 \\
80 \\
175 \\
200 \\
205 \\
230 \\
235 \\
240 \\
245 \\
250 \\
255 \\
260 \\
285 \\
290 \\
295 \\
300\end{array}$ & $\begin{array}{l}15 \\
20 \\
25 \\
30 \\
35 \\
40 \\
45 \\
47.5 \\
50 \\
52.5 \\
55 \\
57.5 \\
60 \\
62.5 \\
65 \\
67.5 \\
70 \\
72.5 \\
75 \\
80 \\
85 \\
180 \\
205 \\
210 \\
235 \\
240 \\
245 \\
250 \\
255 \\
260 \\
265 \\
290 \\
295 \\
300 \\
305\end{array}$ & $\begin{array}{r}2.10 \\
2.20 \\
5.50 \\
4.70 \\
4.90 \\
3.20 \\
1.75 \\
.80 \\
2.30 \\
.20 \\
.15 \\
.10 \\
.05 \\
.05 \\
.20 \\
-.- \\
-.-- \\
.05 \\
-.-- \\
.25 \\
.05 \\
-.-- \\
.75 \\
.10 \\
.05 \\
\text { Tr. } \\
\text { Tr. } \\
.35 \\
\text { Tr. } \\
.25 \\
.10 \\
.25 \\
.10 \\
.20 \\
\text { Tr. }\end{array}$ & $\begin{array}{r}4.10 \\
4.60 \\
7.80 \\
9.30 \\
10.00 \\
5.90 \\
4.50 \\
4.60 \\
3.25 \\
4.25 \\
1.85 \\
1.90 \\
6.25 \\
2.90 \\
2.15 \\
1.70 \\
2.25 \\
4.00 \\
6.00 \\
1.80 \\
1.65 \\
1.75 \\
1.75 \\
1.10 \\
1.15 \\
.95 \\
.75 \\
1.05 \\
1.05 \\
1.10 \\
.90 \\
.75 \\
.55 \\
.90 \\
1.00\end{array}$ & 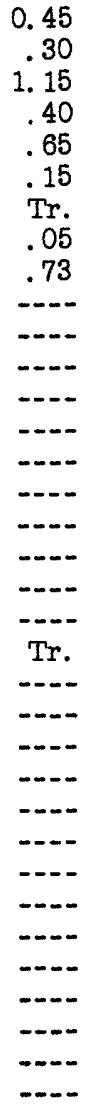 \\
\hline
\end{tabular}

2/ All analysis in the descriptive logs of drill holes are by Frank Walther, analyst, Flatteville, Wis.

Crow Branch no. 2

Location: $1123 \mathrm{ft} \mathrm{N} .21^{\circ} 30^{\prime}$ E. of SE corner sec. 22, T. 5 N., R. $1 \mathrm{~W}$.

Date begun: $9 / 12 / 49$

Date completed: $9 / 21 / 49$

Water table struck: $10 \mathrm{ft}$

Elevation collar: $1012.3 \mathrm{ft}$

Total depth: $365 \mathrm{ft}$

Driller: Judd and Co.

Churn Drill Log

\begin{tabular}{c|c|l|}
\hline \multicolumn{2}{|c|}{ Footage } & \multicolumn{1}{|c|}{ Unit } \\
\hline From & To & \\
15 & 15 & \\
17.5 & 17.5 & Flatteville-(Quimbys Mill) \\
29 & 29 & Flatteville-(McGregor) \\
51 & 51 & Flatteville-(Fecatonica) \\
53 & 53 & Flatteville-(Glenwood) \\
104 & 104 & St. Feter \\
& 140 & Frairie du Chien
\end{tabular}

Description

Residual soil and yellow-buff dolomite, oxidized; pyrite and limonite abundant; little barite, calcite; trace galena.

Dolomite, yellow-buff, dense; brown shale; pyrite, limonite; calcite, considerable galena and sphalerite; trace barite.

Limestone, light-gray; mineralization same; gray shale 28-29'.

Dolomite, gray, mottled; trace sphalerite at 40-45; galena, considerable pyrite and marcasite.

Shale, green, phosphatic, sandy. Little galena, considerable pyrite.

Sandstone, large, rounded, grains; trace of pyrite and marcasite; occasional green shale and calcite; all oxidized.

Dolomite, buff and gray; cherty; oolite 115-120, 125-130, little sphalerite 105-110, 130-135, trace pyrite, marcasite and glauconite. 
Churn Drill Log-Continued.

\begin{tabular}{|c|c|c|c|}
\hline \multicolumn{2}{|c|}{ Footage } & \multirow[b]{2}{*}{ Unit } & \multirow[b]{2}{*}{ Description } \\
\hline From & To & & \\
\hline 140 & 165 & Frairie du Chien & Sandstone and dolomite, buff-tan; trace glauconite, cherty \\
\hline $\begin{array}{l}165 \\
170\end{array}$ & $\begin{array}{l}170 \\
347\end{array}$ & $\begin{array}{l}\text { Frairie du Chien } \\
\text { Frairie du Chien }\end{array}$ & $\begin{array}{l}\text { Quartz and oolite; trace pyrite, marcasite, and glauconite. } \\
\text { Dolomite, buff, light-gray and pink, with quartz; marcasite } \\
\text { and pyrite, trace-fair; trace glauconite, green shale; } \\
\text { occasional oolites. }\end{array}$ \\
\hline 347 & 365 & Trempealeau-(Jordan) & Sandstone; trace pyrite and marcasite. \\
\hline
\end{tabular}

Analyses

\begin{tabular}{l|l|l|l|l}
\hline \multicolumn{2}{|c|}{ Feet } & To & Fe & Fb \\
\hline 15 & 17.5 & 0.30 & 6.90 & 1.40 \\
17.5 & 20 & .25 & 9.90 & 2.35 \\
20 & 23 & .15 & 5.90 & 1.20 \\
23 & 28 & .05 & 3.25 & .40 \\
28 & 30 & --- & 3.70 & .15 \\
30 & 35 & --- & 4.20 &.--- \\
35 & 40 & --- & 4.05 & --- \\
40 & 45 & --- & 4.60 & .90 \\
45 & 50 & --- & 4.80 & .95 \\
50 & 52.5 & --- & 4.25 & .45 \\
105 & 110 & --- & 1.10 &.--- \\
130 & 135 & .10 & 1.75 &.--- \\
& & & & \\
\hline
\end{tabular}

Crow Branch no. 3 (Diamond Drill Log)

Location: $1044 \mathrm{ft} \mathrm{N} .17^{\circ} 30^{\prime}$ E. of southeast corner sec. 22, T. $5 \mathrm{~N}$. , R. $1 \mathrm{~W}$.

Date begun: $7 / 2 / 49$

Date completed: $7 / 26 / 49$

Water table: not reached

Elevation collar: $1008.9 \mathrm{ft}$

Total depth: 121. $2 \mathrm{ft}$

Driller: Frank Balcar

\begin{tabular}{c|r|l|l}
\hline \multicolumn{2}{c|}{ Footage } & \multicolumn{1}{|c}{ Unit } & \multicolumn{1}{c}{ Description } \\
\hline From & To & & \\
\hline 11.2 & 11.2 & & Surficial, \\
20.0 & 20.0 & Flatteville-(McGregor) & Limestone, gray. \\
39.0 & 39.0 & Flatteville-(Fecatonica) & Limestone, buff. \\
41.0 & 41.0 & Flatteville-(Glenwood) & Shale, green, sandy, trace pyrite. \\
& 121.2 & St. Feter & Sandstone, yellow to white. \\
\hline
\end{tabular}

\section{Crow Branch no. 3A}

Location: $1287 \mathrm{ft} \mathrm{N.} 35^{\circ} 15^{\prime}$ E. of southeast corner sec. 22, T. $5 \mathrm{~N} .$, R. $1 \mathrm{~W}$.

Date begun: $9 / 21 / 49$

Date completed: $9 / 29 / 49$

Elevation collar: $1020.1 \mathrm{ft}$.

Water table struck: $9 \mathrm{ft}$

Total depth: $405 \mathrm{ft}$

Driller: Judd and Co.

Churn Drill Log

\begin{tabular}{c|c|l|}
\hline \multicolumn{2}{|c|}{ Footage } & \multicolumn{1}{|c|}{ Unit } \\
\hline From & To & \multicolumn{1}{|c|}{ Decorah-(Ion) } \\
0 & 10 & Decorah-(Ion) \\
10 & 15 & Decorah-(Guttenberg) \\
15 & 28 & Decorah-(Spechts Ferry) \\
28 & 31 & Flatteville-(Quimbys Mill) \\
31 & 35 &
\end{tabular}

Dolomite, yellow-buff, oxidized. Trace pyrite.

Dolomite, blue-gray; trace pyrite.

Limestone, light-tan, dense; trace pyrite, green and brown shale.

Limestone, buff, fossiliferous, phosphatic; gray shale, trace pyrite.

Limestone, dark-brown, dense; trace calcite, pyrite, gray shale. 
Churn Dril! Log-Continued.

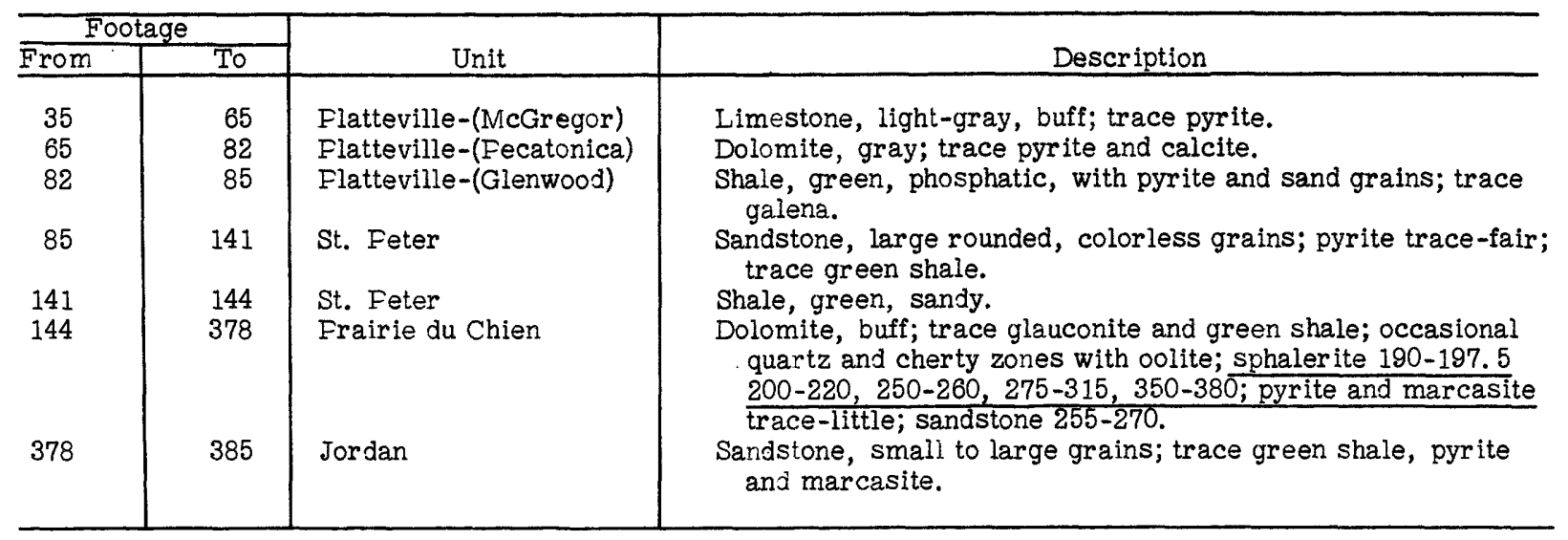

Analyses

\begin{tabular}{|c|c|c|c|c|}
\hline \multicolumn{2}{|c|}{ F'eet } & \multirow[b]{2}{*}{$\mathrm{Zn}$} & \multirow[b]{2}{*}{$\mathrm{Fe}$} & \multirow[b]{2}{*}{$\mathrm{Fb}$} \\
\hline From & To & & & \\
\hline 80 & 85 & .... & 3,25 & $\operatorname{Tr}$ \\
\hline 190 & 195 & 0.50 & .85 & $\ldots$ \\
\hline 195 & 197.5 & .25 & 1.00 & -- \\
\hline 197.5 & 200 & $-\cdots$ & .85 &.- \\
\hline 200 & 202.5 & .10 & 1.00 & $\ldots$ \\
\hline 202.5 & 205 & .10 & 1.00 & $-\cdots$ \\
\hline 205 & 207.5 & .20 & .90 & -- \\
\hline 207.5 & 210 & .15 & .55 & -- \\
\hline 210 & 212.5 & .10 & .75 & -- \\
\hline 212.5 & 215 & .25 & .95 & $\cdots$ \\
\hline 215 & 217.5 & .05 & 1.05 & $\cdots$ \\
\hline 217.5 & 220 & .05 & 1. 10 & $\cdots$ \\
\hline 250 & 255 & .05 & .85 & $\cdots$ \\
\hline 255 & 257.5 & .15 & .90 & -- \\
\hline 257.5 & 260 & .07 & .85 & $\cdots$ \\
\hline 275 & 280 & .05 & .75 & $\cdots$ \\
\hline 285 & 290 & .07 & .55 &.- \\
\hline 290 & 295 & .65 & .80 & $\cdots$ \\
\hline 295 & 300 & .12 & .65 & $\cdots$ \\
\hline 300 & 305 & .08 & .80 & $\rightarrow--$ \\
\hline 310 & 315 & .05 & .80 & $\ldots$ \\
\hline 365 & 370 & $\operatorname{Tr}$. & 1. 05 & $\cdots$ \\
\hline 370 & 375 &.-- & .95 &.- \\
\hline
\end{tabular}

Crow Branch no. 4 (Churn Drill Log)

Location: $1105 \mathrm{ft} \mathrm{N.} 1^{\circ} 30^{\prime}$ E. southeast corner sec. 22, T. 5 N., R. 1 W.

Date begun: $9 / 5 / 49$

Date completed: $9 / 12 / 49$

Water table struck: $93 \mathrm{ft}$

Elevation collar: $1003.2 \mathrm{ft}$

Total depth: $320 \mathrm{ft}$

Driller: Judd and Co.

\begin{tabular}{c|r|l|}
\hline \multicolumn{2}{|c|}{ Footage } & \multicolumn{1}{|c|}{ Unit } \\
\hline From & To & \\
0 & 13 & \\
13 & 18 & Flatteville-(Fecatonica) \\
18 & 22 & Flatteville-(Glenwood) \\
22 & 65 & St. Feter \\
65 & 69 & St. Feter \\
69 & 302 & Frairie du Chien \\
& &
\end{tabular}

\footnotetext{
Description

Soil and stream gravel; placer barite, galena, pyrite and limonite.

Dolomite, gray and buff.

Shale, green, with pyritized sandstone.

Sandstone, clear, rounded, large grains, oxidized; trace pyrite.

Shale, gray-green, with sand grains, glauconite and pyrite.

Dolomite, light-tan, gray, and buff, cherty; trace glauconite shale, pyrite, marcasite; trace chalcopyrite 135-160; a few oolite and sandstone zones; considerable quartz. 
Crow Branch no. 4 (Churn Drill Log)-Continued.

\begin{tabular}{l|l|l|l}
\hline \multicolumn{2}{c|}{ Footage } & Unit & \\
\hline From & To & Description \\
\hline 302 & 320 & Jordan & $\begin{array}{c}\text { Sandstone, medium-grained, friable, oxidized. Trace oolite, } \\
\text { limonite, pyrite, brown and green shale. }\end{array}$ \\
\hline
\end{tabular}

Crow Branch no. 5 (Diamond Drill Log)

Location: $1845 \mathrm{ft} \mathrm{N.} 60^{\circ} 30^{\prime}$ W. of southeast corner sec. 22, T. 5 N., R. $1 \mathrm{~W}$.

Date begun: $7 / 2 / 49$

Date completed: $7 / 5 / 49$

Water table: not reached

Elevation collar: 998.7

Total depth: 76.2

Driller: Frank Balcar

\begin{tabular}{c|r|l|l}
\hline \multicolumn{2}{c|}{ Footage } & \multicolumn{1}{|c}{ Unit } & \multicolumn{1}{c}{ Description } \\
\hline From & To & & \\
\hline 0 & 12.4 & & Surficial. \\
12.4 & 63.7 & St. Feter & Sandstone, white to brown. \\
63.7 & 74.2 & St. Feter & Shale, green. \\
74.2 & 76.2 & Frairie du Chien & Dolomite, buff; trace pyrite. \\
\hline
\end{tabular}

\section{Crow Branch no. 5A (Diamond Drill Log)}

Location: $1830 \mathrm{ft} \mathrm{N} .61^{\circ}$ W. of southeast corner sec. 22, T. 5 N. , R. $1 \mathrm{~W}$.

Date begun: $7 / 15 / 49$

Date completed: $8 / 4 / 49$

Water table: not reached

Elevation collar: $997.8 \mathrm{ft}$

Total depth: $303.6 \mathrm{ft}$

Driller: Frank Balcar

\begin{tabular}{c|r|l|l}
\hline \multicolumn{2}{c|}{ Footage } & \multicolumn{1}{|c}{ Formation } & \\
\hline From & To & & Description \\
\hline 0 & 9 & & Surficial. \\
9 & 60.6 & St. Feter & Sandstone. \\
60.6 & 63.3 & St. Feter & Shale, green. \\
63.3 & 105.5 & Frairie du Chien & Dolomite, buff, cherty; trace pyrite, marcasite. \\
105.5 & 154.0 & Frairie du Chien & Dolomite, gray, chert and drusy quartz; marcasite, pyrite in \\
& & & vugs and fractures. \\
154.0 & 218.0 & Frairie du Chien & Dolomite, varicolored; marcasite, pyrite. \\
218.0 & 281.5 & Frairie du Chien & Dolomite, tan; marcasite. \\
281.5 & 287.2 & Trempealeau-Jordan) & Sandstone; dolomite, green shale streaks; trace marcasite. \\
287.2 & 303.6 & Trempealeau-(Jordan) & Sandstone, brown dolomite, pink; trace marcasite. \\
\end{tabular}

\section{Crow Branch no. 6 (Churn Drill'Log)}

Location: $1882 \mathrm{ft} \mathrm{S} .62^{\circ}$ E. of southeast corner sec. 22, T. 5 N. , R. $1 \mathrm{~W}$.

Date begun: $9 / 15 / 49$

Date completed: $9 / 22 / 49$

Elevation collar: $1134.8 \mathrm{ft}$

Water table struck: $70 \mathrm{ft}$

Total depth: $450 \mathrm{ft}$

Driller: Gille Bros.

\begin{tabular}{c|r|l|l}
\hline \multicolumn{2}{c|}{ Footage } & \multicolumn{1}{|c}{ Unit } & \multicolumn{1}{c}{ Description } \\
\hline From & To & & \multicolumn{1}{|c}{. } \\
0 & 10 & & Surficial deposits. \\
10 & 35 & Galena & Dolomite, buff, cherty; trace limonite. \\
35 & 60 & Galena & Dolomite, buff, cherty; limonite-10 percent Fe. \\
60 & 78 & Galena & Dolomite, buff, cherty; trace limonite-marcasite. \\
78 & 98 & Decorah-(Ion) & Dolomite, gray; pyrite, marcasite. \\
98 & 109 & Decorah-(Guttenberg) & Dolomite, brown; shale, brown; pyrite common. \\
109 & 111 & Decorah-(Spechts Ferry) & Shale, green. \\
111 & 113 & Flatteville-(Quimbys Mill) & Dolomite, brown; shale, brown; pyrite common. \\
113 & 125 & Flatteville-(McGregor) & Dolomite, gray; pyrite and marcasite common. \\
125 & 130 & Flatteville-(McGregor) & Limestone, gray; pyrite and marcasite. \\
130 & 140 & Flatteville-(McGregor) & Dolomite, gray; trace pyrite. \\
140 & 155 & Flatteville-(Fecatonica) & Dolomite, gray-brown; trace pyrite and marcasite. \\
& &
\end{tabular}


Crow Branch no. 6 (Churn Drill Log)-Continued.

\begin{tabular}{l|l|l|l}
\hline \multicolumn{2}{c|}{ Footage } & \multicolumn{1}{c}{ Unit } & \multicolumn{1}{c}{ Description } \\
\hline From & To & & \\
155 & 160 & Flatteville-(Glenwood) & Shale, green, sandy; pyrite common. \\
160 & 197 & St. Feter & Sandstone; trace pyrite. \\
197 & 215 & Frairie du Chien & Dolomite, buff to gray; trace pyrite. \\
215 & 290 & Frairie du Chien & Dolomite, buff to gray, shale, olive, sandy, trace pyrite. \\
290 & 395 & Frairie du Chien & Dolomite, cream; cherty; little pyrite. \\
395 & 425 & Frairie du Chien & Dolomite, silicified, cherty; green shale; trace pyrite. \\
425 & 430 & Frairie du Chien & Dolomite brown; oolite; trace pyrite. \\
430 & 450 & Trempealeau-(Jordan) & Sandstone; brown sandy dolomite; trace pyrite. \\
\hline
\end{tabular}

\section{Crow Branch no. 7 (Churn Drill Log)}

Location: $2030 \mathrm{ft} \mathrm{S} .63^{\circ} 30^{\prime}$ E. of southeast corner sec. 22, T. $5 \mathrm{~N} ., \mathrm{R} .1 \mathrm{~W}$.

Date begun: $2 / 9 / 50$

Date completed: $2 / 22 / 50$

Elevation collar: $1117 \mathrm{ft}$

Water table struck: $60 \mathrm{ft}$

Total depth: $470 \mathrm{ft}$

Driller: Gille Bros.

\begin{tabular}{|c|c|c|c|}
\hline \multicolumn{2}{|c|}{ Footage } & \multirow[b]{2}{*}{ Unit } & \multirow[b]{2}{*}{ Description } \\
\hline From & To & & \\
\hline 0 & 15 & & Residual Soil. \\
\hline 15 & 86 & Galena & Dolomite, yellow-buff, oxidized, cherty. Little limonite. \\
\hline 86 & 100 & Decorah-(Ion) & Dolomite, light-gray; pyrite and marcasite $4-15$ percent. \\
\hline 100 & 105 & Decorah-(Ion) & Dolomite, blue; pyrite and marcasite 20 percent. \\
\hline 105 & 112 & Decorah-(Guttenberg) & Shale, and dolomite; pyrite and marcasite $2-8$ percent. \\
\hline 112 & 115 & Decorah-(Spechts Ferry) & Shale, with phosphate nodules; pyrite and marcasite. \\
\hline 115 & 116 & Flatteville-(Quimbys Mill) & Dolomite, tan, sugary. \\
\hline 116 & 130 & Flatteville-(McGregor) & Shale, blue; pyrite and marcasite 1 percent. \\
\hline 135 & 140 & Elatteville-(McGregor) & Dolomite, blue-gray. \\
\hline 140 & 157 & Flatteville-(Fecatonica) & Dolomite, blue-gray; pyrite and marcasite $0.2-2$ percent. \\
\hline 157 & 160 & Flatteville-(Glenwood) & $\begin{array}{l}\text { Shale, green, sandy, phosphatic; pyrite and marcasite } 3 \\
\text { percent. }\end{array}$ \\
\hline 160 & 233 & St. Feter & $\begin{array}{l}\text { Sandstone, large to small, rounded, colorless-frosted quartz } \\
\text { grains. Little pyrite and marcasite. }\end{array}$ \\
\hline 233 & 270 & Frairie du Chien & $\begin{array}{l}\text { Dolomitic sandstone and dolomite; trace oolite, green shale, } \\
\text { pyrite and marcasite. }\end{array}$ \\
\hline 270 & 280 & Frairie du Chien & $\begin{array}{l}\text { Sandstone, fine-large, rounded, colorless-frosted quartz } \\
\text { grains. }\end{array}$ \\
\hline 280 & 310 & Frairie du Chien & $\begin{array}{l}\text { Dolomite, light-buff to buff; cherty; occasional glauconitic } \\
\text { and green shale. Dolomitic sandstone 305-310; Little pyrite } \\
\text { and marcasite } 300-310 \text {. }\end{array}$ \\
\hline 310 & 330 & Frairie du Chien & $\begin{array}{l}\text { Dolomite, pink and buff. Occasional oolites. Little pyrite, } \\
\text { marcasite, and green shale. }\end{array}$ \\
\hline 330 & 380 & Frairie du Chien & $\begin{array}{l}\text { Dolomite, light-tan, buff, and pink; some sandstone } 330-335 \text {, } \\
340-345,365-370 \text {. Fyrite and marcasite } 0.4-4 \text { percent, } \\
\text { trace chalcopyrite } 370-375 \text {. Occasional trace of green } \\
\text { shale. }\end{array}$ \\
\hline 380 & 395 & Frairie du Chien & $\begin{array}{l}\text { Dolomite, buff. Little pyrite and marcasite. Dolomitic sand- } \\
\text { stone and shale 390-395. Little pyrite and marcasite. }\end{array}$ \\
\hline 395 & 459 & Frairie du Chien & $\begin{array}{l}\text { Dolomite, tan, pink, and buff, with scattered sand grains; } \\
\text { some sandstone stringers. Trace pyrite, marcasite, and } \\
\text { green shale. Quartz and cherty oolite } 445-455 \text {. }\end{array}$ \\
\hline 459 & 470 & Trempealeau-(Jordan) & $\begin{array}{l}\text { Sandstone, fine to large, colorless-frosted, quartz grains. } \\
\text { Trace pyrite and marcasite. }\end{array}$ \\
\hline
\end{tabular}




\section{LEIX FROFERTY}

Leix no. 1

Location: $242 \mathrm{ft}$ north and 265 feet west of southeast corner sec. 30, T. 6 N., R. 1 E. , Leix property, Montfort, Wisconsin.

Date begun: $1 / 7 / 50$

Date completed: $2 / 3 / 50$

Water table struck: $60 \mathrm{ft}$
Elevation collar: $1197.7 \mathrm{ft}$

Total depth: $685 \mathrm{ft}$

Driller: Gille Bros.

Churn Drill Log

\begin{tabular}{|c|c|c|}
\hline \multicolumn{2}{|c|}{ Footage } & \multirow[b]{2}{*}{ Unit } \\
\hline From & To & \\
\hline $\begin{array}{r}0 \\
5 \\
25 \\
70 \\
81\end{array}$ & $\begin{array}{r}5 \\
25 \\
70 \\
81 \\
100\end{array}$ & $\begin{array}{l}\text { Galena } \\
\text { Galena } \\
\text { Galena } \\
\text { Galena }\end{array}$ \\
\hline $\begin{array}{l}100 \\
125 \\
135\end{array}$ & $\begin{array}{l}125 \\
135 \\
140\end{array}$ & $\begin{array}{l}\text { Galena } \\
\text { Decorah-(Ion) } \\
\text { Decorah-(Ion) }\end{array}$ \\
\hline 140 & $14 \theta$ & Decorah-(Guttenberg) \\
\hline 149 & 154 & Decorah-(Spechts Ferry) \\
\hline $\begin{array}{l}154 \\
155\end{array}$ & $\begin{array}{l}155 \\
160\end{array}$ & $\begin{array}{l}\text { Flatteville-(Quimbys Mill) } \\
\text { Flatteville-(McGregor) }\end{array}$ \\
\hline 160 & 170 & Flatteville-(McGregor) \\
\hline 170 & 178 & Flatteville-(McGregor) \\
\hline 178 & 195 & Flatteville-(Fecatonica) \\
\hline 195 & 198 & Flatteville-(Glenwood) \\
\hline $\begin{array}{l}198 \\
249 \\
251\end{array}$ & $\begin{array}{l}249 \\
251 \\
280\end{array}$ & $\begin{array}{l}\text { St. Feter } \\
\text { St. Feter } \\
\text { Frairie du Chien }\end{array}$ \\
\hline 280 & 300 & Frairie du Chien \\
\hline 300 & 310 & Frairie du Chien \\
\hline 310 & 315 & Frairie du Chien \\
\hline 315 & 380 & Frairie du Chien \\
\hline 380 & 415 & Frairie du Chien \\
\hline 415 & 466 & Frairie du Chien \\
\hline 466 & 495 & Trempealeau-(Jordan) \\
\hline $\begin{array}{l}495 \\
545\end{array}$ & $\begin{array}{l}545 \\
590\end{array}$ & $\begin{array}{l}\text { Trempealeau } \\
\text { Trempealeau }\end{array}$ \\
\hline 590 & 607 & Franconia \\
\hline 607 & 625 & Franconia \\
\hline
\end{tabular}

Soll.

Dolomite, yellow-buff; trace pyrite; trace sphalerite 15-20.

Dolomite, yellow-buff; chert fair to common.

Dolomite, buff; trace pyrite and marcasite.

Dolomite, yellow-buff; chert fair amount to common; trace barite $90-95$; trace pyrite and marcasite $81-85$; trace pyrite 95-100.

Dolomite, yellow-buff; chert abundant 100-115, little 115-125.

Dolomite, buff and gray; trace pyrite and marcasite.

Shale, gray-green; trace calcite, phosphate nodulas; marcasite and pyrite.

Dolomite, $\tan$ and brown; phosphate nodules; trace chert and quartz; little brown shale; sphalerite abundant;140-150; heavy pyrite.

Limestone; light-buff; fair sphalerite 150-154; phosphate nodules; gray shale.

Shale and dolomite, chocolate brown; fair sphalerite 154-155.

Dolomite, gray; little sphalerite, marcasite and pyrite; trace calcite.

Limestone; light-gray, argillaceous; trace sphalerite and pyrite.

Limestone, light-gray to $\tan$, argillaceous; calcite common; trace sphalerite; little pyrite.

Dolomite, gray-blue; little green shale; trace calcite; trace pyrite and sphalerite.

Shale, green, sandy; abundant pyrite; phosphate nodules common.

Sandstone; pyrite fairly common; little green and gray shale.

Shale, greenish-gray; trace pyrite.

Dolomite, tan, buff, and light-buff; trace green and yellow shale, glauconite, pyrite and marcasite.

Dolomite, sandy, and dolomitic sandstone; trace glauconite, pyrite, marcasite. Cherty oolite 290-300.

Dolomite, sandy; light-tan and cherty oolite; little green and yellow shale.

Dolomite, light-buff; sandstone 20 percent; shale 20 percent; trace oolite, glauconite, pyrite and marcasite.

Dolomite, buff, light-buff, grayish; fair green and buff shale; trace pyrite and marcasite; considerable quartz and cherty oolite 325-335, 365-380; silicified dolomite 340-345.

Dolomite, buff, light-buff; little sphalerite $395-405$, little pyrite and marcasite.

Dolomite, buff, and tan; little chert, green shale, trace marcasite and pyrite; trace sphalerite 430-460; quartz 455-466; trace glauconite.

Sandstone; little glauconitic shale, quartz; trace oolite 466470 , and pyrite.

Dolomite, sandy; trace pyrite and marcasite.

Dolomite, $\tan$ to buff; trace pyrite and marcasite, fair at 550-565, trace green shale.

Dolomite and dolomitic sandstone; very glauconitic; green shale; trace pyrite and marcasite.

Sandstone and siltstone; very glauconitic; green shale, pyrite 3-4 percent, sphalerite 0.1 percent $615-625$. 
Churn Drill Log-Continued.

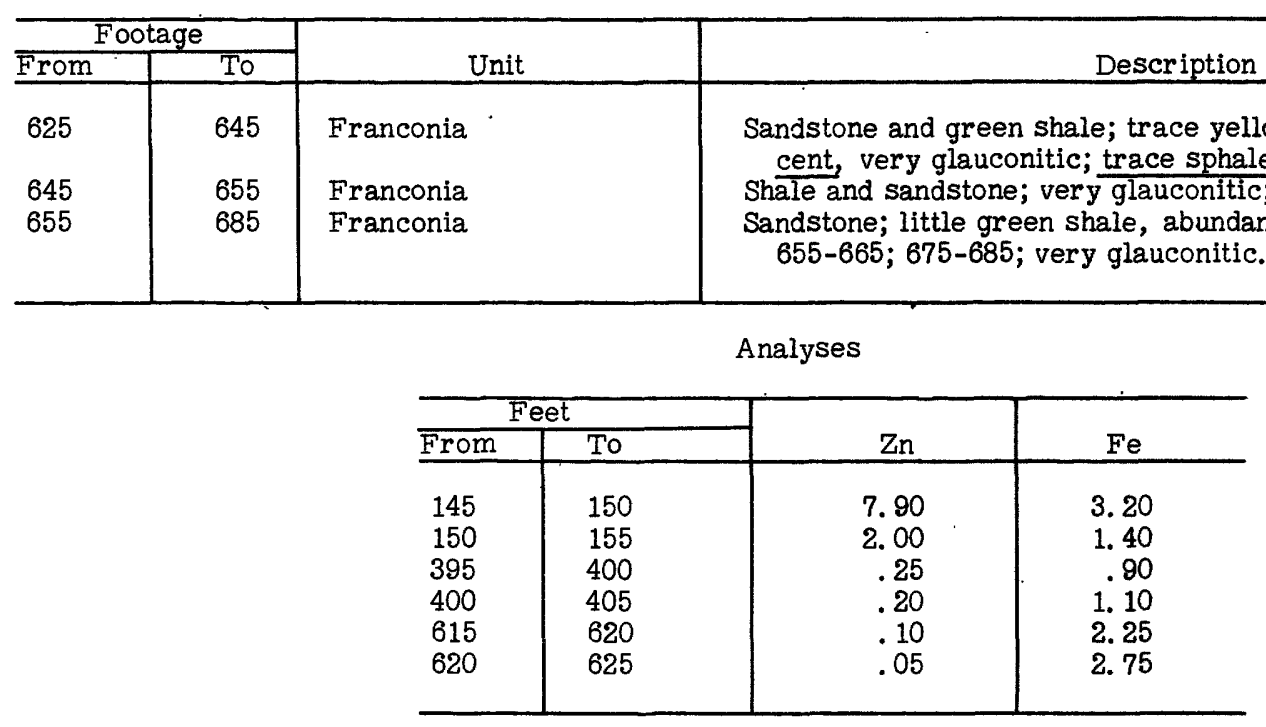




\section{HARRIS FROFERTY}

\section{Harris no. 1}

Location: $35 \mathrm{ft}$ east, 50 feet north of southeast corner NWtNWt sec. $31, T$. 5 N., R. $3 \mathrm{E}$.

Date begun: $1 / 7 / 50$

Date completed: $1 / 21 / 50$

Elevation collar: $1081.2 \mathrm{ft}$

Water table struck: $130 \mathrm{ft}$

Total depth: $370 \mathrm{ft}$

Driller: Judd and Co.

Churn Drill Log

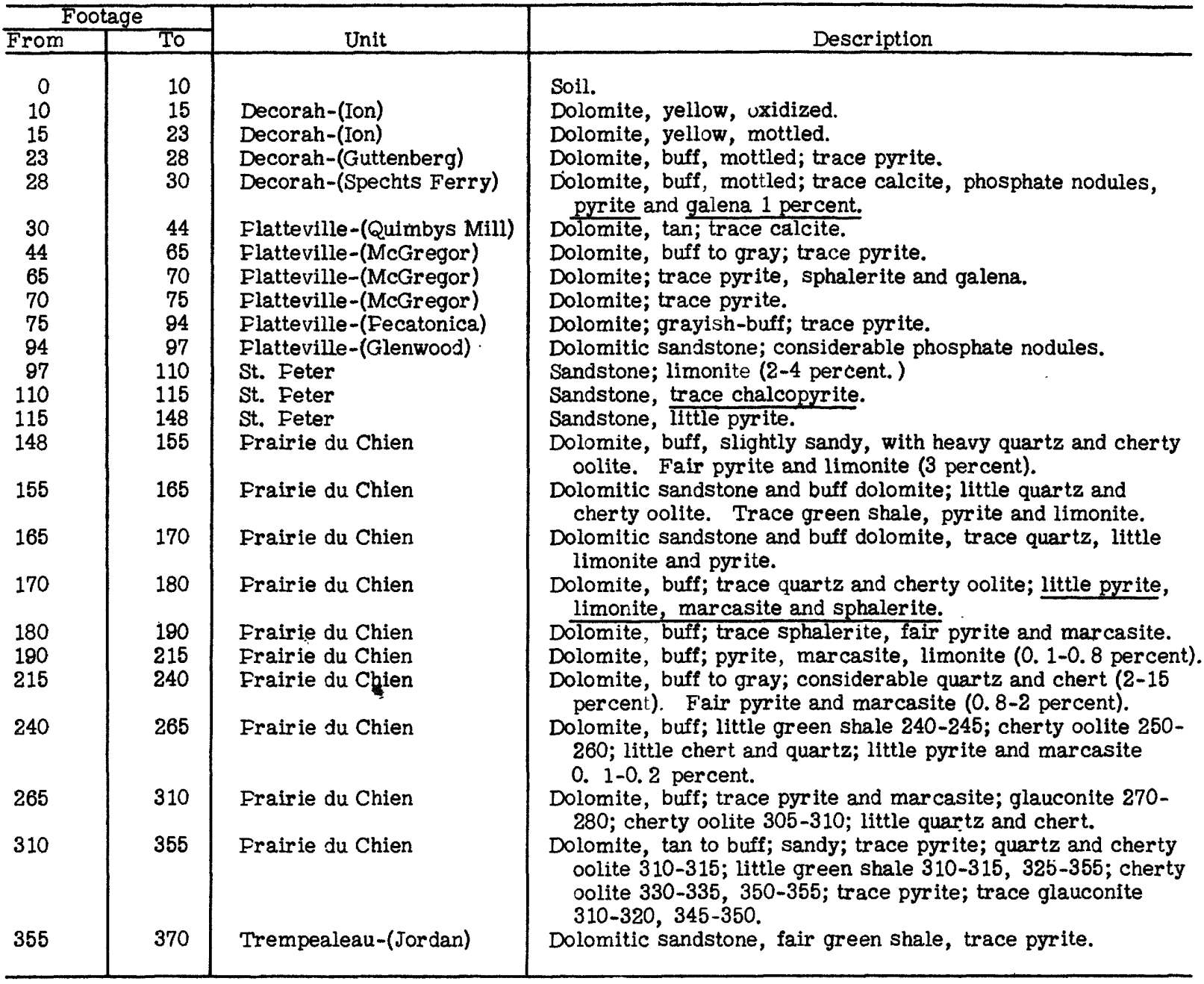

Analyses

\begin{tabular}{l|l|l|l}
\hline \multicolumn{2}{|c|}{ Feet } & Zn & Fe \\
\hline From & To & 0.20 & 1.10 \\
170 & 175 & .25 & 1.55 \\
175 & 180 & & \\
\hline
\end{tabular}




\section{SFITZBARTH FROFERTY}

\section{Spitzbarth no. 1}

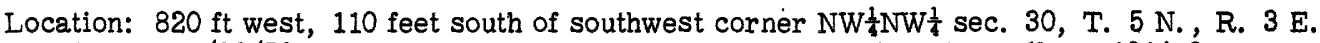

Date begun: $1 / 23 / 50$

Date completed: $2 / 6 / 50$

Elevation collar: 1014.2

Water table struck: $43 \mathrm{ft}$

Total depth: $275 \mathrm{ft}$

Driller: Judd and Son.

Churn Drill Log

\begin{tabular}{|c|c|c|c|}
\hline \multicolumn{2}{|c|}{ Footage } & \multirow[b]{2}{*}{ Unit } & \multirow[b]{2}{*}{ Description. } \\
\hline From & To & & \\
\hline 0 & 15 & & Soil and residual material. \\
\hline 15 & 71 & & $\begin{array}{l}\text { Sandstone; trace chert and green shale, limonite; few phosphate } \\
\text { nodules. }\end{array}$ \\
\hline 71 & 75 & Frairie du Chien & $\begin{array}{l}\text { Dolomite, buff, oxidized; some brown and green shale; cherty } \\
\text { oolite and quartz; trace limonite. }\end{array}$ \\
\hline 75 & 80 & Frairie du Chien & $\begin{array}{l}\text { Dolomitic sandstone; dolomite, buff; oxidized; trace pyrite and } \\
\text { limonite. }\end{array}$ \\
\hline 80 & 85 & Frairie du Chien & Dolomite, buff, oxidized; trace pyrite and limonite. \\
\hline 85 & 90 & Frairie du Chien & Dolomitic sandstone, oxidized. \\
\hline 90 & 95 & Frairie du Chien & Dolomite, buff, oxidized, trace pyrite and limonite. \\
\hline 95 & 125 & Prairie du Chien & $\begin{array}{l}\text { Dolomite, buff, sphalerite, quartz, marcasite and pyrite from } \\
100-120 \text { feet. }\end{array}$ \\
\hline 125 & 235 & Frairie du Chien & $\begin{array}{l}\text { Dolomite, pinkish to grayish-buff; trace sphalerite, pyrite, } \\
\text { marcasite, glauconite. }\end{array}$ \\
\hline 235 & 260 & Frairie du Chien & Dolomite, sandy, tan, trace pyrite and marcasite. \\
\hline 260 & 265 & Frairie du Chien & $\begin{array}{l}\text { Dolomite, sandy, tan ; cherty oolite, trace pyrite and mar- } \\
\text { casite. }\end{array}$ \\
\hline 265 & 275 & Frairie du Chien & $\begin{array}{l}\text { Dolomite, sandy, and dolomitic sandstone, cherty oolite; } \\
\text { trace pyrite and marcasite. }\end{array}$ \\
\hline
\end{tabular}

Analyses

\begin{tabular}{l|c|c|c}
\hline \multicolumn{2}{c|}{ Feet } & Zn & Fe \\
\hline From & To & 0.2 & 1.55 \\
100 & 105 & .1 & 1.0 \\
105 & 110 & .35 & 1.25 \\
110 & 115 & .2 & .65 \\
115 & 120 & & \\
\hline
\end{tabular}




\section{KENNEDY MINE FROFERTY}

\section{Kennedy no. 1}

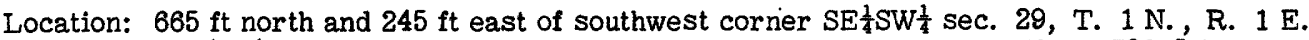

Date begun: $9 / 24 / 49$

Date completed: $10 / 12 / 49$

Elevation collar: $792.5 \mathrm{ft}$

Water table struck: $75 \mathrm{ft}$

Total depth: $520 \mathrm{ft}$

Driller: Gille Bros.

\section{Churn Drill Log}

\begin{tabular}{|c|c|c|c|}
\hline \multicolumn{2}{|c|}{ Footage } & \multirow[b]{2}{*}{ Unit } & \multirow[b]{2}{*}{ Description } \\
\hline From & To & & \\
\hline 0 & 90 & Galena & $\begin{array}{l}\text { Dolomite, yellowish-buff and buff, cherty; sphalerite } 15-20 \text {, } \\
70-95 \text {; little limonite, pyrite and marcasite. }\end{array}$ \\
\hline 90 & 105 & Deçorah-(Ion) & $\begin{array}{l}\text { Dolomite, gray and buff; little sphalerite, pyrite, and mar- } \\
\text { casite. }\end{array}$ \\
\hline 105 & 114 & Decorah-(Ion) & $\begin{array}{l}\text { Dolomite, gray-blue, mottled; little sphalerite, marcasite, } \\
\text { pyrite and calcite. }\end{array}$ \\
\hline 114 & 119 & Decorah-(Guttenberg) & $\begin{array}{l}\text { Dolomite, light-and dark-tan, dense; little sphalerite, fair } \\
\text { pyrite. }\end{array}$ \\
\hline 118 & 120 & Decorah-(Spechts Ferry) & $\begin{array}{l}\text { Limestone, buff, argillaceous, fossiliferous; phosphate } \\
\text { nodules; little chert and shale; trace galena and sphalerite; } \\
\text { fair pyrite. }\end{array}$ \\
\hline 120 & 126 & Flatteville-(Quimbys Mill) & $\begin{array}{l}\text { Limestone and shale, brown; sphalerite } 1.4 \text { percent; pyrite } \\
2.4 \text { percent. }\end{array}$ \\
\hline 126 & 155 & Flatteville-(McGregor) & $\begin{array}{l}\text { Limestone, light-gray and buff; little calcite and pyrite; trace } \\
\text { green shale. }\end{array}$ \\
\hline $\begin{array}{l}155 \\
173\end{array}$ & $\begin{array}{l}173 \\
175\end{array}$ & $\begin{array}{l}\text { Platteville-(Fecatonica) } \\
\text { Flatteville-(Glenwood) }\end{array}$ & $\begin{array}{l}\text { Dolomite, gray and light-gray, mottled; trace pyrite } 155-160 . \\
\text { Shale, green; phosphate nodules; fair pyrite. }\end{array}$ \\
\hline 175 & 294 & St. Feter & $\begin{array}{l}\text { Sandstone, large to medium grained, with pyritic inclusions; } \\
\text { little green and gray shale; considerable pyrite; } 2-2.5 \text { per- } \\
\text { cent from } 285-294 \text {. }\end{array}$ \\
\hline $\begin{array}{l}294 \\
305\end{array}$ & $\begin{array}{l}305 \\
355\end{array}$ & $\begin{array}{l}\text { St. Peter } \\
\text { Frairie du Chien }\end{array}$ & $\begin{array}{l}\text { Shale, green and red-brown, with sand grains; little pyrite. } \\
\text { Dolomite, buff; sandy } 325-340 \text {; little green and brown shale } \\
\text { abundant } 325-330 ; \text { trace pyrite. }\end{array}$ \\
\hline 355 & 400 & Prairie du Chien & $\begin{array}{l}\text { Quartz and chert; dolomite } 368-375,380-386 \text {; trace pyrite and } \\
\text { marcasite, little green and gray shale. }\end{array}$ \\
\hline 400 & 475 & Frairie du Chien & $\begin{array}{l}\text { Dolomite, buff and pink; little quartz, abundant } 411-417 \text {; little } \\
\text { quartz sand } 425-430 \text {, pyrite and marcasite, trace-fair; } \\
\text { cherty oolite } 470-475 \text {. }\end{array}$ \\
\hline 475 & 496 & Frairie du Chien & $\begin{array}{l}\text { Dolomite, buff and pink; sandstone } 475-478 \text {; fair pyrite and } \\
\text { marcasite; cherty oolite } 475-480,490-495 \text {; little black to } \\
\text { green shale. }\end{array}$ \\
\hline 496 & 520 & Trempealeau-(Jordan) & $\begin{array}{l}\text { Sandstone, pink and buff; some dolomites; little pyrite, } \\
\text { marcasite, and quartz; green to black shale, 496-500. }\end{array}$ \\
\hline
\end{tabular}

Analyses

\begin{tabular}{r|r|c|c}
\hline \multicolumn{2}{|c|}{ Feet } & Zn & Fe \\
\hline From & To & 1.90 & 2.65 \\
75 & 80 & 1.00 & 1.90 \\
80 & 85 & .65 & 2.00 \\
85 & 90 & .50 & 1.50 \\
90 & 95 & 1.40 & 2.40 \\
120 & 125 & & 2.40 \\
285 & 290 & & 1.90 \\
290 & 295 & & 2.35 \\
455 & 460 & & 1.30 \\
465 & 470 & & 1.00 \\
490 & 495 & & \\
\hline
\end{tabular}


Kennedy no. 2

Location: $1230 \mathrm{ft}$ east and $630 \mathrm{ft}$ north of southwest corner sec. 29, T. $1 \mathrm{~N} .$, R. 1 .

Date begun: $10 / 3 / 48$

Date completed: $10 / 27 / 49$

Elevation collar: 800.8

Total depth: $580 \mathrm{ft}$

Driller: Judd and Co.

Churn Drill Log

\begin{tabular}{|c|c|c|c|}
\hline \multicolumn{2}{|c|}{ Footage } & \multirow[b]{2}{*}{ Unit } & \multirow[b]{2}{*}{ Description } \\
\hline From & To & & \\
\hline 0 & 100 & Galena & $\begin{array}{l}\text { Dolomite, yellow-buff and buff, cherty; sphalerite, pyrite } \\
\text { and marcasite; trace-fair from } 40-100 \text {; trace galena } 45- \\
72,85-100 \text {. }\end{array}$ \\
\hline 100 & 117 & Decorah-(Ion) & $\begin{array}{l}\text { Dolomite, light-gray and buff; little sphalerite, marcasite, } \\
\text { pyrite, and calcite. }\end{array}$ \\
\hline 117 & 125 & Decorah-(Ion) & $\begin{array}{l}\text { Dolomite, blue-gray, mottled; slightly sandy; trace sphalerite, } \\
\text { pyrite and marcasite. }\end{array}$ \\
\hline 125 & 135 & Decorah-(Guttenberg) & $\begin{array}{l}\text { Dolomite and limestone, light-tan, dense; very good } \\
\text { sphalerite, abundanf marcasite and pyrite; little galena. }\end{array}$ \\
\hline 135 & 138 & Decorah-(Spechts Ferry) & $\begin{array}{l}\text { Limestone, buff, mottled, fossiliferous, with phosphate } \\
\text { nodules. Fair sphalerite, marcasite and pyrite common, } \\
\text { trace galena and calcite. }\end{array}$ \\
\hline 138 & 148 & Flatteville-(Quimbys Mill) & $\begin{array}{l}\text { Limestone, chocolate-brown, dense; fair sphalerite, mar- } \\
\text { casite and pyrite; trace galena; calcite. }\end{array}$ \\
\hline 148 & 180 & Flatteville-(McGregor) & $\begin{array}{l}\text { Limestone, light-gray to buff, mottled; sphalerite, marcasite } \\
\text { and pyrite trace-fair. Calcite } 150-160 \text {, trace gray shale } \\
165-175 \text {. }\end{array}$ \\
\hline $\begin{array}{l}180 \\
201\end{array}$ & $\begin{array}{l}201 \\
205\end{array}$ & $\begin{array}{l}\text { Flatteville-(Fecatonica) } \\
\text { Flatteville-(Glenwood) }\end{array}$ & $\begin{array}{l}\text { Dolomite, light-gray to buff; trace pyrite and marcasite. } \\
\text { Shale, green, very sandy; fair pyrite. }\end{array}$ \\
\hline 205 & 295 & St. Feter & $\begin{array}{l}\text { Sandstone, medium to large grains; trace pyrite and marcasite } \\
\text { black opaque grains } 240-285 \text {. }\end{array}$ \\
\hline 295 & 340 & Frairie du Chien & $\begin{array}{l}\text { Dolomite, buff; cherty oolite } 325-340 \text {; little green, gray, and } \\
\text { brown shales; pyrite trace-fair. }\end{array}$ \\
\hline 340 & 365 & Frairie du Chien & $\begin{array}{l}\text { Dolomite, buff, and green, brown, and gray shale; with } \\
\text { cherty oolite; quartz common; trace pyrite and marcasite. }\end{array}$ \\
\hline 365 & 520 & Frairie du Chien & $\begin{array}{l}\text { Dolomite, pink and buff; considerable quartz; trace pyrite } \\
\text { and marcasite; dolomitic sandstone } 505-515 \text {. }\end{array}$ \\
\hline 520 & 530 & Trempealeau-(Jordan) & Sandstone; with quartz; trace pyrite and marcasite. \\
\hline
\end{tabular}

Analyses

\begin{tabular}{l|l|c|c|c}
\hline \multicolumn{2}{c|}{ Feet } & Zn & Fe & Fb \\
\hline From & To & 1.75 & 5.60 & Tr. \\
82 & 85 & 2.65 & 7.85 & Tr. \\
85 & 87.5 & 3.35 & 7.55 & Tr. \\
87.5 & 90 & 1.50 & 4.65 & 0.10 \\
90.0 & 92.5 & 1.00 & 4.40 & Tr. \\
92.5 & 95 & .70 & 3.15 & Tr. \\
95 & 97.5 & 8.10 & 16.10 & -- \\
125 & 130 & 7.40 & 22.40 & -- \\
130 & 132.5 & 5.00 & 10.70 & -- \\
132.5 & 135 & 1.40 & 6.90 & -- \\
135 & 137.5 & .40 & 2.10 & -- \\
137.5 & 140 & 1.50 & 1.60 & Tr. \\
140 & 145 & .80 & 1.20 & Tr. \\
145 & 147.5 & .50 & 1.60 & $-\cdots$ \\
155 & 160 & & & \\
\hline
\end{tabular}

Kennedy no. 3 (Core Drill Log)

Location: $1305 \mathrm{ft} \mathrm{N} .60^{\circ}$ E. of southwest corner sec. 29, T. $1 \mathrm{~N} .$, R. $1 \mathrm{E}$.

Date begun: $8 / 8 / 49$

Date completed: $8 / 16 / 49$

Water table: not reached
Elevation collar: $808 \mathrm{ft}$

Total depth: $240.9 \mathrm{ft}$

Driller: Frank Balcar 
Kennedy no. 3 (Core Drill Log)-Continued

\begin{tabular}{c|c|l|l}
\hline \multicolumn{2}{c|}{ Footage } & \multicolumn{1}{|c}{ Unit } & \\
\hline From & To & & Description \\
\hline 0 & 6 & & Surficial material. \\
6 & 104.5 & Galena & \\
104.5 & 120.5 & Decorah-(Ion) & \\
120.5 & 129 & Decorah-(Ion) & \\
129 & 142.5 & Decorah-(Guttenberg) & \\
142.5 & 146 & Decorah-(Spechts Ferry) & \\
146 & 155 & Flatteville-(Quimbys Mill) & \\
155 & 189 & Flatteville-(McGregor) & \\
189 & 210 & Flatteville-(Fecatonica) & Shale, green; sandstone; phosphate nodules. \\
210 & 213 & Flatteville-(Glenwood) & Sandstone, gray. \\
213 & 229 & St. Feter & Sandstone, white to yellowish. \\
229 & 240.9 & St. Feter & \\
\hline
\end{tabular}

Kennedy no. 3A (Churn Drill Log 0-291 feet,

\section{Diamond Drill Log 291-424 feet)}

Location: $990 \mathrm{ft} \mathrm{N.} 63^{\circ}$ E. of southwest corner sec. 29, T. 1 N. , R. 1 E.

Date begun: $8 / 20 / 49$

Date completed: $9 / 3 / 49$

Water table: not reached
Elevation collar: $808.7 \mathrm{ft}$

Total depth: $424 \mathrm{ft}$

Driller: 0-291, Judd \& Son

291-424, Frank Balcar

\begin{tabular}{|c|c|c|c|}
\hline \multicolumn{2}{|c|}{ Footage } & \multirow[b]{2}{*}{ Unit } & \multirow[b]{2}{*}{ Description } \\
\hline From & To & & \\
\hline 0 & 10 & & Soil and residual material. \\
\hline 10 & 50 & Galena & Dolomite, buff, oxidized, cherty; trace limonite. \\
\hline 50 & 85 & Galena & Dolomite, buff, cherty; trace limonite, pyrite. \\
\hline 85 & 90 & Galena & Same, with trace sphalerite. \\
\hline 90 & 95 & Galena & Same, no sphalerite. \\
\hline 95 & 100 & Galena & Same, shine sphalerite. \\
\hline 100 & 110 & Galena & Same, no sphalerite. \\
\hline 110 & 115 & Decorah-(Ion) & $\begin{array}{l}\text { Dolomite, gray, trace shale, green, marcasite and pyrite, } \\
\text { limonite; shine sphalerite. }\end{array}$ \\
\hline 115 & 125 & Decorah-(Ion) & Same, no sphalerite. \\
\hline 125 & 130 & Decorah-(Ion) & Same, trace sphalerite. \\
\hline 130 & 144 & Decorah-(Guttenberg) & Iimestone, buff; brown shale; pyrite. \\
\hline 144 & 145 & Decorah-(Spechts Ferry) & Shale, green. \\
\hline 145 & 156 & Flatteville-(Quimbys Mill) & Limestone, brown; shale, brown pyrite. \\
\hline 156 & 188 & Flatteville-(McGregor) & Limestone, gray. \\
\hline 188 & 210 & Flatteville-(Fecatonica) & Dolomite, gray. \\
\hline 210 & 212 & Flatteville-(Glenwood) & Shale, green, sandy. \\
\hline 212 & 285 & St. Feter & Sandstone. \\
\hline 285 & 291 & St. Feter & Sandstone, pink; light-green shale. \\
\hline 291 & 311 & Frairie du Chien & Dolomite, gray, siliceous; shale, green cryptozoon. \\
\hline 311 & 312.1 & Frairie du Chien & Sandstone. \\
\hline 312. 1 & 319 & Frairie du Chien & Dolomite, gray. \\
\hline 319 & 319.7 & Frairie du Chien & Shale, green and red; glauconite. \\
\hline 319.7 & 352.5 & Frairie du Chien & Dolomite, gray, and dolomitic sandstone, glauconitic to 322 . \\
\hline 352.5 & 365.2 & Frairie du Chien & Shale, green, sandy, glauconitic; trace pyrite. \\
\hline 365.2 & 389.4 & Frairie du Chien & Dolomite, buff, cherty; glauconite. \\
\hline 389.4 & 405.6 & Frairie du Chien & $\begin{array}{l}\text { Shale, grayish-jreen; dolomite, buff sandstone and oolite at } \\
\text { base. }\end{array}$ \\
\hline 405. 6 & 409. 1 & Frairie du Chien & Sandstone, dolomitic, argillaceous. \\
\hline 409.1 & 411.3 & Frairie du Chien & Dolomite, shale, green; sandstone. \\
\hline 411.3 & 414.3 & Frairie du Chien & Sandstone. \\
\hline 414.3 & 417.3 & Frairie du Chien & Dolomite; sandstone. \\
\hline 417.3 & 422 & Frairie du Chien & Dolomite; oolitic; glauconite. \\
\hline 422 & 424 & Frairie du Chien & Cotton rock. \\
\hline
\end{tabular}




\section{Kennedy no. 3B (Churn Drill Log)}

Location: $990 \mathrm{ft} \mathrm{N} .63^{\circ}$ E. of southwest corner sec. 29, T. 1 N., R. 1 E.

Date begun: $2 / 9 / 50$

Date completed: $2 / 28 / 50$

Elevation collar: 808.7

Total depth: $525 \mathrm{ft}$

Water table struck: $80 \mathrm{ft}$

Driller: Judd and Son

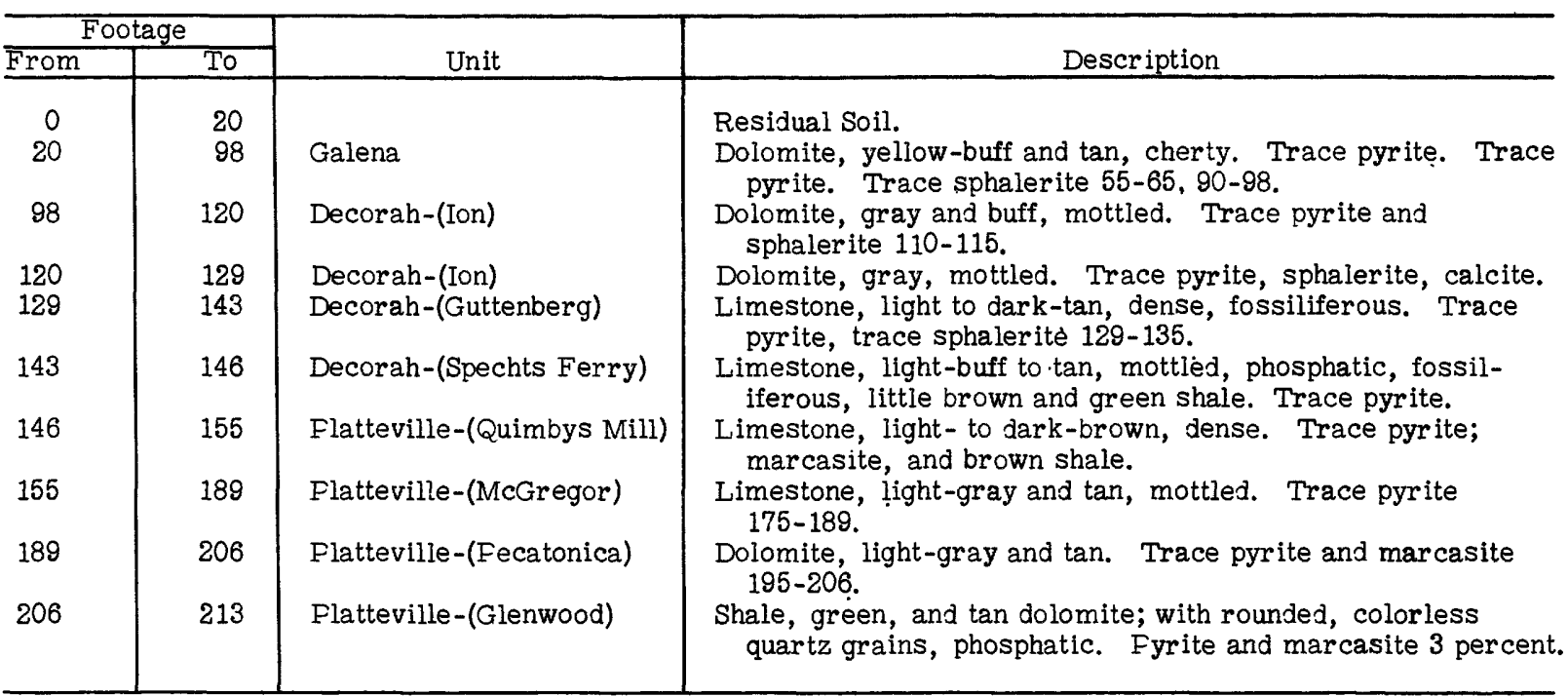


Location: $655 \mathrm{ft} \mathrm{N} .60^{\circ}$ E. of southwest corner sec. 29, T. 1 N. , R. $1 \mathrm{E}$.

Date begun: $10 / 15 / 49$

Date completed: $10 / 29 / 49$

Elevation collar: $845 \mathrm{ft}$

Total depth: $570 \mathrm{ft}$

Water table struck: $120 \mathrm{ft}$

Driller: Gille Bros.

\begin{tabular}{|c|c|c|c|}
\hline \multicolumn{2}{|c|}{ Footage } & \multirow[b]{2}{*}{ Unit } & \multirow[b]{2}{*}{ Description } \\
\hline From & To & & \\
\hline 0 & 20 & & No sample. \\
\hline 20 & 35 & Galena & Dolomite, buff. \\
\hline 35 & 142 & Galena & Dolomite, buff, cherty; trace limonite. \\
\hline 142 & 155 & Decorah-(Ion) & Dolomite, gray, trace pyrite and marcasite. \\
\hline 155 & 161 & Decorah-(Ion) & Limestone, gray mottled. \\
\hline 161 & 175 & Decorah-(Guttenberg) & Limestone, buff; shale, brown; little pyrite. \\
\hline 175 & 180 & Galena-(Spechts Ferry) & Limestone, white argillaceous, phosphate nodules; pyrite $2 \%$. \\
\hline 180 & 190 & Flatteville-(Quimbys Mill) & Limestone, brown; shale, brown; trace pyrite. \\
\hline 190 & 225 & Platteville-(McGregor) & Limestone, grayish, argillaceous, trace pyrite. \\
\hline 225 & 245 & Flatteville-(Fecatonica) & Dolomite, brownish; little pyrite. \\
\hline 245 & 251 & Flatteville-(Glenwood) & Shale, green; sandstone, argillaceous, pyrite $7 \%$. \\
\hline 251 & 295 & St. Feter sandstone & Sandstone, pyrite $3 \%$. \\
\hline 295 & 325 & St. Feter sandstone & Sandstone, little pyrite. \\
\hline 325 & 330 & St. Feter sandstone & Sandstone; shale, light green; trace pyrite. \\
\hline 330 & 340 & Frairie du Chien & Dolomite, gray to brown, siliceous, trace pyrite. \\
\hline 340 & 345 & Frairie du Chien & Same, with oolite; trace pyrite. \\
\hline 345 & 385 & Frairie du Chien & Same, no oolite; glauconite; shale, green, with white mica. \\
\hline 385 & 390 & Frairie du Chien & Green shale as above; shale, red, micaceous. \\
\hline 390 & 400 & Frairie du Chien & Shale, red, micaceous. \\
\hline 400 & 450 & Frairie du Chien & $\begin{array}{l}\text { Dolomite, buff, cherty, oolitic } 405-410,425-430 \text {; glauconitic } \\
430-435 \text {, trace of pyrite; shale, green, red. }\end{array}$ \\
\hline 450 & 465 & Frairie du Chien & Same, but no pyrite; oolite; shale, green, red. \\
\hline 465 & 495 & Frairie du Chien & Shale, purplish, green; oolite, chert, dolomite. \\
\hline 495 & 550 & Frairie du Chien & Chert, shales as above, dolomite and oolite at base. \\
\hline 550 & 570 & Jordan & Chert, siliceous dolomite; sandstone; green shale, little pyrite \\
\hline
\end{tabular}




\section{James no. 1. (Diamond Drill Log)}

Location: $1510 \mathrm{ft} \mathrm{S.} 53^{\circ}$ E. of northwest corner SWt sec. 9, T. 1 N. , R. 2 E.

Date begun: $7 / 29 / 49$

Date completed: $8 / 30 / 49$

Elevation collar: $943.8 \mathrm{ft}$

Water table struck: not recorded.

Driller: Frank Balcar

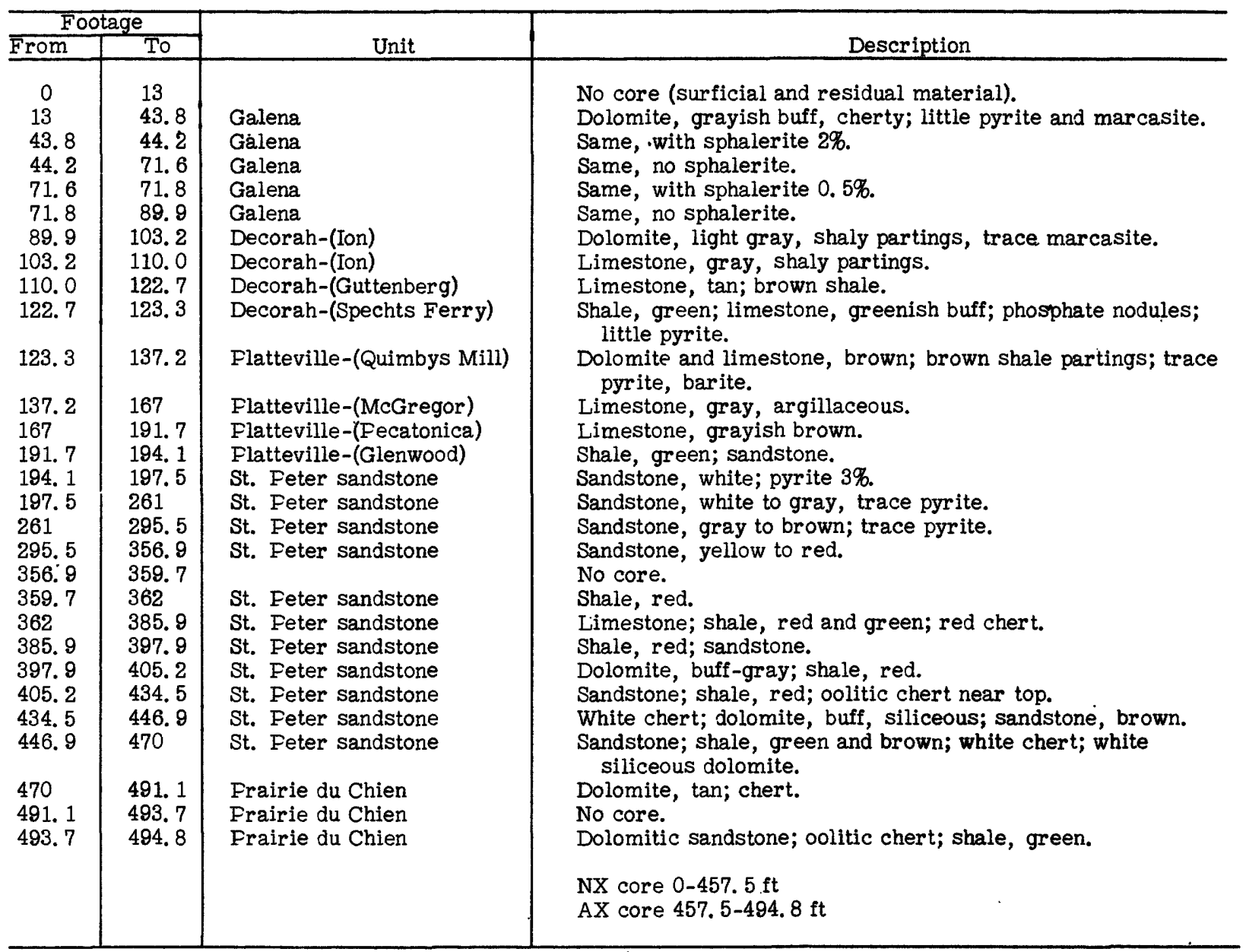




\section{MEEKERS GROVE AREA (RAISBECK FROPERTY)}

\section{Raisbeck no. 1 (Churn Drill Log)}

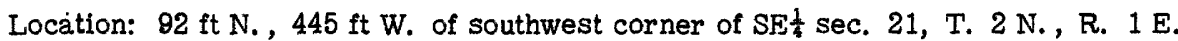

Date begun: $10 / 29 / 49$

Date completed: $11 / 5 / 49$

Elevation collar: $1002.6 \mathrm{ft}$

Water table struck: $165 \mathrm{ft}$

Total depth: $475 \mathrm{ft}$

Driller: Judd and Co.

\begin{tabular}{|c|c|c|c|}
\hline \multicolumn{2}{|c|}{ Footage } & \multirow[b]{2}{*}{ Unit } & \multirow[b]{2}{*}{ Description } \\
\hline From & To & & \\
\hline 0 & 18 & & Soil. \\
\hline 18 & 33 & Galena & Dolomite, yellow-buff, cherty, limonitic. \\
\hline 33 & 45 & Decorah-(Ion) & Limestone, gray, mottled, fossiliferous; limonitic. \\
\hline 45 & 52 & Decorah-(Ion) & Limestone, blue, mottled, limonitic. \\
\hline 52 & 66 & Decorah-(Guttenberg) & $\begin{array}{l}\text { Limestone, } \tan \text {, buff; trace pyrite; little calcite; phosphate } \\
\text { nodules. }\end{array}$ \\
\hline 66 & 71 & Decorah-(Spechts Ferry) & $\begin{array}{l}\text { Limestone, buff, very fossiliferous; abundant phosphate } \\
\text { nodules; little green shale; trace pyrite. }\end{array}$ \\
\hline 71 & 78 & Flatteville-(Quimbys Mill) & Limestone, chocolate brown; $\tan$ and dense; trace pyrite. \\
\hline 78 & 110 & Platteville-(McGregor) & $\begin{array}{l}\text { Limestone, light gray and buff; fossiliferous } 90-110 \text {; trace } \\
\text { pyrite. }\end{array}$ \\
\hline 110 & 132 & Flatteville-(Fecatonica) & Limestone and dolomite, gray, tan; trace pyrite, calcite. \\
\hline 132 & 136 & Platteville-(Glenwood) & Shale, green, with sand grains. Fyrite common, little galena \\
\hline 136 & 368 & St. Feter sandstone & $\begin{array}{l}\text { Sandstone, grains well-rounded; orange colored } 150-350 \text {; blacl } \\
\text { opaque grains 235-368; trace galena, little pyrite at top. }\end{array}$ \\
\hline 368 & 397 & Frairie du Chien & $\begin{array}{l}\text { Dolomite, buff and pink; cherty } 368-375 \text {; trace pyrite and } \\
\text { marcasite; little pink and green shale. }\end{array}$ \\
\hline 397 & 426 & Frairie du Chien & $\begin{array}{l}\text { Shale, green, red-brown, with little sand grains; trace } \\
\text { pyrite and marcasite. }\end{array}$ \\
\hline 426 & 450 & Frairie du Chien & $\begin{array}{l}\text { Sandstone; chert } 30 \% \text {; secondary silicification } 30 \% \text {; trace } \\
\text { green shale, marcasite, and pyrite. }\end{array}$ \\
\hline 450 & 455 & Frairie du Chien & $\begin{array}{l}\text { Chert and quartz; little green and red shale; trace pyrite and } \\
\text { marcasite. }\end{array}$ \\
\hline 455 & 460 & Frairie du Chien & $\begin{array}{l}\text { Chert, brown-green shale, and quartz; trace pyrite and } \\
\text { marcasite. }\end{array}$ \\
\hline 460 & 475 & Jordan & $\begin{array}{l}\text { Sandstone; red-green shale common; trace pyrite and } \\
\text { marcasite. }\end{array}$ \\
\hline
\end{tabular}

Raisbeck no. 2 (Churn Drill Log)

Location: $1840 \mathrm{ft} \mathrm{N}$, $930 \mathrm{ft}$. W. of southwest corner SE $\frac{1}{4}$ sec. 21, T. 2 N. , R. $1 \mathrm{E}$.

Date begun: $10 / 29 / 49$

Date completed: $11 / 7 / 49$

Elevation collar: $914 \mathrm{ft}$

Water table struck: $30 \mathrm{ft}$

Total depth: $445 \mathrm{ft}$

Driller: Gille Bros.

\begin{tabular}{|c|c|c|c|}
\hline \multicolumn{2}{|c|}{ Footage } & \multirow[b]{2}{*}{ Unit } & \multirow[b]{2}{*}{ Description } \\
\hline From & To & & \\
\hline 0 & 7 & & No samples (soil and residual material). \\
\hline 7 & 10 & Decorah-(Ion) & Limestone, gray; trace pyrite. \\
\hline 10 & 22 & Decorah-(Guttenberg) & Limestone, brown; trace brown shale. \\
\hline 22 & 25 & Decorah-(Spechts Ferry) & Limestone, gray, little pyrite. \\
\hline 25 & 32 & Flatteville-(Quimbys Mill) & Dolomite, brown; brown shale, little pyrite. \\
\hline 32 & 67 & Flatteville-(McGregor) & Dolomite, gray, argillaceous; trace pyrite. \\
\hline 67 & 95 & Platteville-(Fecatonica) & Dolomite, buff to gray; pyrite $1 \%$. \\
\hline 86 & 95 & Flatteville-(Glenwood) & Shale, green, sandy, glauconitic; pyrite $2 \%$. \\
\hline 95 & 120 & St. Feter sandstone & Sandstone, pyrite $3 \%$. \\
\hline 120 & 130 & St. Feter sandstone & Sandstone, pyrite $0.5 \%$ \\
\hline 130 & 145 & St. Feter sandstone & Sandstone, argillaceous $;$ pyrite $2 \%$. \\
\hline 145 & 285 & St. Feter sandstone & Sandstone, pyrite $0.5 \%$ \\
\hline 285 & 415 & St. Feter sandstone & Sandstone, gray, little pyrite. \\
\hline 415 & 420 & St. Feter sandstone & Sandstone, shale, light green, pyrite $0.7 \%$. \\
\hline 420 & 435 & St. Feter sandstone & $\begin{array}{l}\text { Shale, red; shale, olive; shale, light gray; sandstone; trace } \\
\text { pyrite. }\end{array}$ \\
\hline 435 & 445 & Cambrian? & Dolomite, siliceous, glauconitic. \\
\hline
\end{tabular}




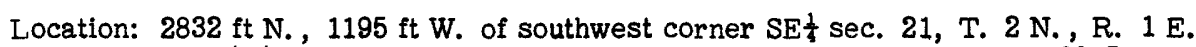

Date begun: $11 / 7 / 49$

Date completed: $11 / 17 / 49$

Water table struck: $42 \mathrm{ft}$
Elevation: $890.5 \mathrm{ft}$

Total depth: $450 \mathrm{ft}$

Driller: Judd and Company

\begin{tabular}{|c|c|c|c|}
\hline \multicolumn{2}{|c|}{ Footage } & \multirow[b]{2}{*}{ Unit } & \multirow[b]{2}{*}{ Description } \\
\hline From & To & & \\
\hline 0 & 65 & Galena & $\begin{array}{l}\text { Dolomite, yellow-buff; cherty, little limonite, pyrite and } \\
\text { marcasite - 4-8\% at 50-65; calcite common. }\end{array}$ \\
\hline 65 & 82 & Decorah-(Ion) & $\begin{array}{l}\text { Dolomite, gray and buff, mottled; calcite common; pyrite and } \\
\text { marcasite } 2 \% \text {. }\end{array}$ \\
\hline 82 & $88^{\circ}$ & Decorah-(Ion) & $\begin{array}{l}\text { Dolomite, blue, mottled; pyrite and marcasite } 4-10 \% \text {, little } \\
\text { sphalerite; calcite. }\end{array}$ \\
\hline 88 & 88 & Decorah-(Guttenberg) & $\begin{array}{l}\text { Limestone, tan, dense, fossiliferous; calcite; pyrite and } \\
\text { marcasite } 2 \% \text {; little sphalerite. }\end{array}$ \\
\hline 98 & 102 & Decorah-(Spechts Ferry) & $\begin{array}{l}\text { Shale, green and limestone, buff, very fossiliferous; } \\
\text { phosphate nodules; little pyrite and marcasite, trace } \\
\text { galena. }\end{array}$ \\
\hline 102 & 105 & Flatteville-(Quimbys Mill) & $\begin{array}{l}\text { Dolomite, tan-brown, fine-grained; calcite common, pyrite } \\
\text { and marcasite } 1.5 \% \text {. }\end{array}$ \\
\hline 105 & 111 & Flatteville-(Quimbys Mill) & $\begin{array}{l}\text { Limestone, tan-brown, partially dolomitized; calcite common } \\
\text { pyrite and marcasite } 1.5 \% \text {, trace sphalerite. }\end{array}$ \\
\hline 111 & 140 & Flatteville-(McGregor) & $\begin{array}{l}\text { Limestone, buff; trace sphalerite; fair pyrite and marcasite; } \\
\text { calcite. }\end{array}$ \\
\hline 140 & 160 & Flatteville-(Fecatonica) & $\begin{array}{l}\text { Dolomite, light gray; little calcite, trace pyrite and } \\
\text { marcasite. }\end{array}$ \\
\hline 160 & 161 & Flatteville-(Glenwood) & Shale, green-white; pyrite $2.5 \%$ \\
\hline 161 & 289 & St. Feter sandstone & $\begin{array}{l}\text { Sandstone; little green shale } 161-175 \text {, black opaque sand } \\
\text { grains } 250-289 \text {; trace pyrite and marcasite. }\end{array}$ \\
\hline 289 & 292 & St. Feter sandstone & Shale, green, sandy; trace pyrite and marcasite. \\
\hline $\begin{array}{l}292 \\
295\end{array}$ & 295 & Frairie du Chien & Sandstone and dolomite, buff. \\
\hline 300 & 310 & $\begin{array}{l}\text { Frairie du Chien } \\
\text { Frairie du Chien }\end{array}$ & $\begin{array}{l}\text { Dolomite, buff; little green shale, trace pyrite. } \\
\text { Shale, green and dolomite, buff-pink; trace pyrite and }\end{array}$ \\
\hline $310^{\circ}$ & 450 & Frairie du Chien & $\begin{array}{l}\text { marcasite. } \\
\text { Dolomite, buff, pink; little shale, green and white; abundant } \\
\text { at } 305-310 ; 405-410 ; 440-445 ; \text { cherty oolite } 380-395 \text {; trace } \\
\text { pyrite and marcasite. }\end{array}$ \\
\hline
\end{tabular}




\section{Vinegar Hill Roaster no. 1}

Location: NEtNEt NEt sec. 6, T. 1 N., R. 1 E.

Date begun: $12 / 5 / 49$

Date completed: $12 / 21 / 49$

Water table struck: $30 \mathrm{ft}$
Elevation collar: $950.3 \mathrm{ft}$

Total depth: $500 \mathrm{ft}$

Driller: Gille Bros.

Churn Drill Log

\begin{tabular}{|c|c|c|c|}
\hline \multicolumn{2}{|c|}{ Footage } & \multirow[b]{2}{*}{ Unit } & \multirow[b]{2}{*}{ Description } \\
\hline From & To & & \\
\hline 0 & 15 & & Soil and residual material. \\
\hline 15 & 32 & Galena & $\begin{array}{l}\text { Dolomite, yellow buff to gray, cherty; trace pyrite, } \\
\text { marcasite, limonite. }\end{array}$ \\
\hline 32 & 90 & Galena & $\begin{array}{l}\text { Dolomite, buff to gray, cherty, considerable pyrite, } \\
\text { limonite, sphalerite. }\end{array}$ \\
\hline 90 & 100 & Decorah-(Ion) & $\begin{array}{l}\text { Dolomite, light blue gray; trace sphalerite, pyrite, } \\
\text { marcasite. }\end{array}$ \\
\hline 100 & 108 & Decorah-(Ion) & $\begin{array}{l}\text { Dolomite, blue gray; abundant pyrite and marcasite; and } \\
\text { trace of sphalerite. }\end{array}$ \\
\hline 108 & 112 & Decorah-(Guttenberg) & $\begin{array}{l}\text { Limestone, tan; abundant pyrite and marcasite, trace of } \\
\text { sphalerite. }\end{array}$ \\
\hline 112 & 115 & Decorah-(Spechts Ferry) & $\begin{array}{l}\text { Shale, green; some limestone, buff; trace sphalerite, little } \\
\text { pyrite and marcasite. }\end{array}$ \\
\hline 115 & 120 & Flatteville-(Quimbys Mill) & Limestone, brown; trace sphalerite, marcasite and pyrite. \\
\hline 120 & 142 & Flatteville-(McGregor) & Limestone, gray-buff; trace sphalerite, marcasite, pyrite. \\
\hline 142 & 168 & Flatteville-(Fecatonica) & Dolomite gray buff; trace sphalerite, marcasite and pyrite. \\
\hline 168 & 175 & Flatteville-(Glenwood) & Shale, green, sandy; trace pyrite and marcasite. \\
\hline 175 & 220 & St. Feter sandstone & Sandstone; trace pyrite. \\
\hline 220 & 225 & St. Feter sandstone & Sandstone; green and white shale; trace pyrite. \\
\hline 225 & 235 & Frairie du Chien & Dolomite, buff; trace pyrite. \\
\hline 235 & 260 & Prairie du Chien & Dolomite, buff; trace pyrite, glauconite. \\
\hline 260 & 275 & Frairie du Chien & Dolomite buff; trace pyrite; marcasite. \\
\hline 275 & 285 & Frairie du Chien & $\begin{array}{l}\text { Dolomite, buff; cherty; trace cherty oolite, trace pyrite, } \\
\text { glauconite. }\end{array}$ \\
\hline 285 & 300 & Frairie du Chien & $\begin{array}{l}\text { Dolomite and dolomitic sandstone; chert, oolite; trace pyrite } \\
\text { and marcasite. }\end{array}$ \\
\hline 300 & 320 & Frairie du Chien & Dolomite, buff; trace pyrite, glauconite. \\
\hline 320 & 325 & Frairie du Chien & Dolomite, and dolomitic sandstone; trace pyrite. \\
\hline 325 & 370 & Frairie du Chien & Dolomite, buff, silicified, cherty; trace pyrite. \\
\hline 370 & 385 & Frairie du Chien & $\begin{array}{l}\text { Dolomite and sandstone; cherty oolite; trace pyrite and } \\
\text { marcasite. }\end{array}$ \\
\hline 385 & 405 & Frairie du Chien & $\begin{array}{l}\text { Dolomite, buff, cherty and silicified; cherty oolite; trace } \\
\text { pyrite and marcasite. }\end{array}$ \\
\hline 405 & 445 & Frairie du Chien & Same without the oolite. \\
\hline 445 & 450 & Prairie du Chien & $\begin{array}{l}\text { Dolomite, tan, silicified; cherty oolite, little marcasite and } \\
\text { coarsely crystalline sphalerite; quartz, fractured ground. }\end{array}$ \\
\hline 450 & 455 & Frairie du Chien & Same, without the oolite, trace chalcopyrite. \\
\hline 455 & 470 & Frairie du Chien & Dolomite, $\tan$, silicified, cherty; little marcasite, oolite. \\
\hline 470 & 475 & Frairie du Chien & Same, without the oolite. \\
\hline 475 & 490 & Frairie du Chien & $\begin{array}{l}\text { Dolomitic sandstone and dolomite; trace marcasite and } \\
\text { pyrite. }\end{array}$ \\
\hline 490 & 492 & Frairie du Chien & Shale, green; dolomitic sandstone. \\
\hline 492 & 500 & Jordan & $\begin{array}{l}\text { Sandstone, little sphalerite, marcasite and pyrite; trace } \\
\text { glauconite: }\end{array}$ \\
\hline
\end{tabular}

Analyses

\begin{tabular}{l|c|c|c}
\hline \multicolumn{2}{c|}{ Feet } & Zn & Fe \\
\hline From & To & 1.3 & 3.00 \\
50 & 55 & 1.1 & 3.15 \\
55 & 60 & 1.35 & 4.75 \\
65 & 70 & 3.25 & 4.55 \\
70 & 75 & & \\
\hline
\end{tabular}

